\title{
Interplay of Support Chemistry and Reaction Conditions on Copper Catalyzed Methanol Steam Reforming
}

\author{
Manuel Antonio Díaz-Pérez, ${ }^{\dagger}$ Javier Moya, $^{\dagger}$ Juan Carlos Serrano-Ruiz, $^{\dagger, \ddagger(0)}$ and Jimmy Faria* ${ }^{\dagger} \dagger, \S(0)$ \\ ${ }^{\dagger}$ Abengoa Research, C/Energía Solar 1, Campus Palmas Altas, Sevilla, 41014, Spain \\ "Universidad de Loyola, Andalucía, Department of Engineering, C/Energía Solar 1, Campus Palmas Altas, Sevilla, 41014, Spain \\ ${ }^{\S}$ Chemical Processes and Materials, Faculty of Science and Technology, University of Twente, Enschede, The Netherlands
}

Supporting Information

\begin{abstract}
A series of $\mathrm{Cu}$ catalysts supported on $\mathrm{SiO}_{2}, \mathrm{Al}_{2} \mathrm{O}_{3}-\mathrm{SiO}_{2}, \mathrm{TiO}_{2}$ rutile, and $\mathrm{Cu} / \mathrm{TiO}_{2}$ anatase metal oxides has been studied for methanol reforming in the vapor phase. The highest activity was obtained on $\mathrm{Cu} / \mathrm{SiO}_{2}$ catalysts $\left(5493 \mu \mathrm{mol} \mathrm{H}_{2} \mathrm{~min}^{-1} \cdot \mathrm{g}_{\mathrm{cat}}{ }^{-1}\right.$ ) followed by $\mathrm{Cu} / \mathrm{TiO}_{2}$ rutile, $\mathrm{Cu} /$ $\mathrm{Al}_{2} \mathrm{O}_{3}-\mathrm{SiO}_{2}$, and anatase. XRD and HRTEM characterization after reaction revealed that on $\mathrm{Cu} / \mathrm{SiO}_{2}$ significant sintering occurred during reaction. In contrast, the particle size growth on $\mathrm{Cu} / \mathrm{TiO}_{2}$ rutile and anatase was less pronounced, which could be associated with the interaction between $\mathrm{Cu}$ clusters and $\mathrm{TiO}_{2}$. Characterization by TGA showed that on $\mathrm{Cu} / \mathrm{Al}_{2} \mathrm{O}_{3}-\mathrm{SiO}_{2}$ the main cause of deactivation was coke deposition.
\end{abstract}

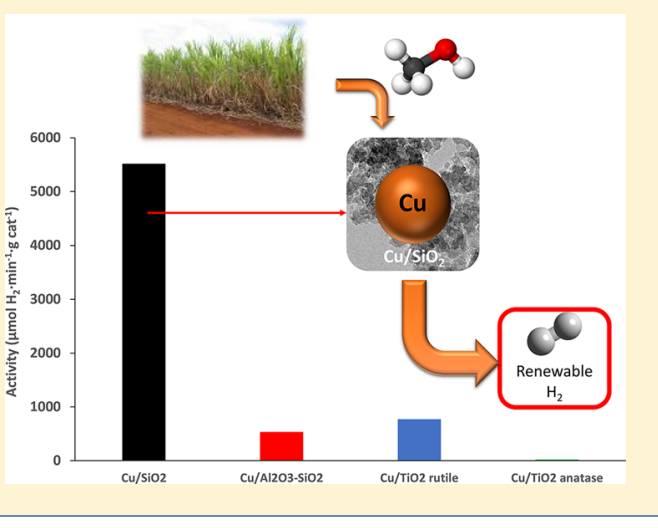

\section{INTRODUCTION}

Industrial production of hydrogen is accomplished via steam reforming of natural gas or light oil fractions. However, the utilization of fossil-derived feeds hinders its long-term application due to the concomitant greenhouse emissions and environmental pollution. Over the past decade, significant efforts have been made to accelerate the transition to more sustainable hydrogen sources (e.g., bioethanol, biomethanol, biodiesel, and $\left.\mathrm{H}_{2} \mathrm{O}\right){ }^{1}$ In particular, steam reforming of methanol (see reaction 1) offers several advantages when compared to reforming of other renewable feedstocks. Methanol is one of the most efficient energy carriers due to its high molecular $\mathrm{H} / \mathrm{C}$ ratio (four hydrogen atoms per carbon). Unlike ethanol, the absence of recalcitrant $\mathrm{C}-\mathrm{C}$ bonds favors the reforming process at low temperatures (240$260{ }^{\circ} \mathrm{C}$ ), reducing the risk of coke formation typically observed in ethanol reforming $\left(350-800{ }^{\circ} \mathrm{C}\right)$. At the same time, operation at lower temperatures reduces the $\mathrm{CO}$ formation since methanol thermal decomposition (see reaction 2) is inhibited at low temperatures. Additionally, utilization of low temperatures is beneficial for the water-gas shift reaction (WGS; see reaction 3), which leads to low levels of $\mathrm{CO}$ in the reformate stream. ${ }^{2}$ As a result, it is possible to avoid the use of specialized materials in the reactor construction, lowering the overall cost of the system. ${ }^{3}$ Finally, operating at relatively mild conditions minimizes undesired surface reconstruction and particle sintering during reaction. ${ }^{4}$

$$
\begin{gathered}
\mathrm{CH}_{3} \mathrm{OH}+\mathrm{H}_{2} \mathrm{O} \rightarrow \mathrm{CO}_{2}+3 \mathrm{H}_{2} \\
\Delta H_{298 \mathrm{~K}}^{\circ}=+49.7\left(\mathrm{~kJ} \mathrm{~mol}^{-1}\right)
\end{gathered}
$$

$$
\begin{aligned}
& \mathrm{CH}_{3} \mathrm{OH} \rightarrow \mathrm{CO}+2 \mathrm{H}_{2} \quad \Delta H_{298 \mathrm{~K}}^{\circ}=+90.7\left(\mathrm{~kJ} \mathrm{~mol}^{-1}\right) \\
& \mathrm{CO}+\mathrm{H}_{2} \mathrm{O} \leftrightarrow \mathrm{CO}_{2}+\mathrm{H}_{2} \quad \Delta H_{298 \mathrm{~K}}^{\circ}=-41.1\left(\mathrm{~kJ} \mathrm{~mol}^{-1}\right)
\end{aligned}
$$

Copper supported on $\mathrm{ZnO} / \mathrm{Al}_{2} \mathrm{O}_{3}$ oxides is the most commonly used catalyst for methanol steam reforming due to its high activity at low temperatures and high selectivity to $\mathrm{H}_{2}{ }^{5,6,15-24,7,25,8-14}$ In this catalyst, oxygenated molecules bind with the "ideal" strength and configuration to metallic $\mathrm{Cu}$, which facilitates the activation of water molecules and methanol on the surface to produce carboxyl- and carbonylcontaining species that can easily undergo decomposition to $\mathrm{CO}_{2}$ and $\mathrm{H}_{2}{ }^{11,13,26,27}$ This results in high selectivity to the reforming products (i.e., $\mathrm{CO}_{2}$ and $\mathrm{H}_{2}$ ) and very low decarbonylation and methanation byproducts (i.e., $\mathrm{CO}$ and $\left.\mathrm{CH}_{4}\right){ }^{4}$ For this reason, $\mathrm{Cu}$ catalysts have been the subject of extensive research using partially reducible metal oxides (e.g., $\mathrm{CeO}_{2}$ and $\left.\mathrm{TiO}_{2}\right)^{4,5,34-40,6,19,28-33}$ and nonreducible metal oxides (e.g., $\mathrm{SiO}_{2}, \mathrm{Al}_{2} \mathrm{O}_{3}$ ) as catalyst supports. $4,5,34,6,19,28-33$

Recently, it has been shown that $\mathrm{Cu} / \mathrm{ZnO}-\mathrm{Al}_{2} \mathrm{O}_{3}$ is an extremely dynamic catalytic system under industrial reaction conditions as evidenced by in situ and ex situ characterization using bulk, surface sensitive, and imaging methods. ${ }^{41}$ These catalysts undergo significant structural changes that drastically

Received: July 6, 2018

Revised: October 15, 2018

Accepted: October 24, 2018

Published: October 24, 2018 
affect the selectivity, activity, and ultimately stability of the $\mathrm{Cu}$ catalysts. ${ }^{42}$ Therefore, understanding the nature of the interactions between $\mathrm{Cu}$ clusters and metal oxides is of primary interest to successfully design new catalytic materials with improved catalytic activity, selectivity, and stability. For this reason, in this study, we decided to evaluate the performance of a copper catalyst supported on metal oxides with different surface reducibility, acidity, topology, and crystalline structure to establish activity-structure relationships. For this purpose, we synthesized, characterized, and tested a set of $\mathrm{Cu}$ catalysts supported on nanosized $\mathrm{SiO}_{2}$, $\mathrm{Al}_{2} \mathrm{O}_{3}-\mathrm{SiO}_{2}, \mathrm{TiO}_{2}$ rutile, and $\mathrm{TiO}_{2}$ anatase for methanol steam reforming. In addition, the effect of pressure was investigated for the most active catalyst $\left(\mathrm{Cu} / \mathrm{SiO}_{2}\right)$. At high pressures, it will be possible to directly connect the reactor effluent to a membrane separation unit, decreasing the associated capital and operational costs as the membrane footprint will be substantially reduced. ${ }^{43}$ This high-purity hydrogen can be fed to a refuelling station at higher pressures, reducing the number of compression stages required to reach the 600 bar of pressure required in mobility applications. ${ }^{44,45}$

\section{EXPERIMENTAL SECTION}

2.1. Materials. The methanol used in the reaction was Chromasolv HPLC grade purchased from Sigma-Aldrich with a purity above $99.9 \%$. Copper(II) nitrate trihydrate used as a precursor was also obtained from Sigma-Aldrich (purity $\geq 99 \%$ ). The four supports used and their descriptions can be found in Table 1 .

Table 1. Description and Physical Properties of the Supports Employed for Catalyst Synthesis

\begin{tabular}{|c|c|c|c|}
\hline support & description & supplier & $\begin{array}{l}\text { BET surface area } \\
\qquad\left(\mathrm{m}^{2} \mathrm{~g}^{-1}\right)\end{array}$ \\
\hline $\mathrm{SiO}_{2}$ & Aerosil 380 & Evonik & $350-410$ \\
\hline $\begin{array}{l}\mathrm{Al}_{2} \mathrm{O}_{3}-\mathrm{SiO}_{2}(70 \% / \\
30 \%)\end{array}$ & Siral $40 \mathrm{HPV}$ & Sasol & 500 \\
\hline $\mathrm{TiO}_{2}(100 \%$ rutile $)$ & & Sigma-Aldrich & 50 \\
\hline $\begin{array}{l}\mathrm{TiO}_{2}(100 \% \\
\text { anatase })\end{array}$ & $\begin{array}{l}\text { Crystal Activ } \\
\text { G5 }\end{array}$ & $\begin{array}{l}\text { Crystal France } \\
\text { SAS }\end{array}$ & 370 \\
\hline
\end{tabular}

2.2. Catalyst Synthesis. Four different supports were selected to study the performance of copper based catalysts on the methanol steam reforming reaction in the vapor phase. The catalysts studied were prepared by wet impregnation using copper(II) nitrate tryhidrate as a precursor with a loading of 20 wt $\%$. The salt was dissolved using DI water, and the support was added while the solution was stirred $(500 \mathrm{rpm})$. The dispersion was stirred for $48 \mathrm{~h}$ at room temperature before evaporating the solvent at $110{ }^{\circ} \mathrm{C}$, maintaining continuous stirring $(200 \mathrm{rpm})$. After this step, the solid was dried at 100 ${ }^{\circ} \mathrm{C}$ overnight. Once the powder was completely dried, it was calcined at $600{ }^{\circ} \mathrm{C}$ over $4 \mathrm{~h}\left(10^{\circ} \mathrm{C} \mathrm{min}{ }^{-1}\right)$.

2.3. Catalyst Characterization. The catalysts were characterized by temperature-programmed reduction (TPR), temperature-programmed desorption of $\mathrm{NH}_{3}\left(\mathrm{NH}_{3}-\mathrm{TPD}\right), \mathrm{N}_{2}$ physisorption, thermal gravimetric analysis (TGA), X-ray diffraction (XRD), and transmission electron microscopy (TEM). TPR characterization of $30 \mathrm{mg}$ of catalyst was performed on a Micromeritics Autochem II 2920 using a gas mixture of $10 \% \mathrm{H}_{2}$ in $\mathrm{Ar}$ at a flow rate of $50 \mathrm{~mL} \mathrm{~min}^{-1}$ with a linear heating rate of $5{ }^{\circ} \mathrm{C} \mathrm{min}^{-1}$ up to $900{ }^{\circ} \mathrm{C}$ and holding time of $1 \mathrm{~min} . \mathrm{H}_{2}$ consumption was determined by a thermal conductivity detector. $\mathrm{NH}_{3}$-TPD was measured using Micromeritics Autochem II 2920 employing a gas mixture of 15 vol $\% \mathrm{NH}_{3} / \mathrm{He}$. The surface was initially cleaned with $\mathrm{He}$, then it was reduced in $50 \mathrm{sccm}$ of $\mathrm{H}_{2} / \mathrm{Ar} 10 / 90 \mathrm{vol} \%$ at $230{ }^{\circ} \mathrm{C}$ for 3 $\mathrm{h}$ to replicate the reduction conditions employed during the catalyst activation. Then, the system was purged with $\mathrm{He}$ at $230{ }^{\circ} \mathrm{C}$ to remove any water formed. Once the temperature reached $35{ }^{\circ} \mathrm{C}, 15 \% \mathrm{NH}_{3} / \mathrm{He}$ was passed through the sample for $60 \mathrm{~min}$. Finally, a temperature ramp of $10^{\circ} \mathrm{C} \mathrm{min}^{-1}$ up to $900{ }^{\circ} \mathrm{C}$ was employed to study the desorption profile. Total acidity of the catalysts was determined by integrating the area under the curve of the $\mathrm{NH}_{3}$-TPD. The desorption was measured by thermal conductivity detector (TCD). Nitrogen adsorption isotherms were obtained using a Micromeritics ASAP 2020. The data were fitted using Brunauer-EmmettTeller (BET) theory to calculate surface area and porous size distribution. The physisorption of nitrogen was performed at liquid nitrogen temperature $(77 \mathrm{~K})$, and the degasification step was carried out at $200{ }^{\circ} \mathrm{C}$ over $4 \mathrm{~h}$. Prior to analysis, the samples were degassed in situ at $230{ }^{\circ} \mathrm{C}$ for $24 \mathrm{~h}$. The micropore volume was derived from the t-plot method (relative pressure range: $0.2-0.6$ ), and the total pore volume was determined at $p / p_{0}=0.99$. Surface areas were measured before and after reaction. The crystallinity of the sample and the identification of the crystalline species were determined using a D8I Bruker XRD for powder samples with incident slits and with a $\mathrm{Cu}$ anode working at $40 \mathrm{kV}$ and $40 \mathrm{~mA}$. The data were collected in an angle range from 30 to $60^{\circ}$. A semiquantitative method was used to determine the crystalline structure by comparison to the database of Joint Committee on Powder Diffraction Standards (JCPDS). The average size of the crystallites was calculated using the Debye-Scherrer eq (eq 4).

$$
\tau=\frac{0.9 \times \lambda}{\beta \times \cos \theta}
$$

For the HRTEM characterization, a Philips CM200 microscope $(200 \mathrm{kV})$ with a structural resolution of $0.14 \mathrm{~nm}$ between lines and $0.23 \mathrm{~nm}$ between points equipped with $\mathrm{X}$ ray Energy Dispersive Analyzer (EDX X-Max 80T, Oxford Instruments) and a CCD GATAN camera for image acquisitions was employed to characterize the nanostructure of the catalysts. Each sample was prepared by sonicating the powder in n-butanol to improve the dispersion of the particles. The catalyst particles were dropwise transferred to a holey carbon coated 300 mesh copper grid. The catalysts were characterized before and after reaction. TGA experiments were performed in a TA Instruments SDT Q-600 thermobalance. The TGA analyses were performed using high purity air to measure the amount of carbon deposited on the catalyst. The first step consists of an increasing temperature ramp from 25 to $110{ }^{\circ} \mathrm{C}$ at a rate of $5{ }^{\circ} \mathrm{C} \min ^{-1}$. Once $110{ }^{\circ} \mathrm{C}$ is reached, the temperature is maintained for $20 \mathrm{~min}$ before carrying out a quenching to $40{ }^{\circ} \mathrm{C}$. Then, the temperature is increased to 550 ${ }^{\circ} \mathrm{C}$ at a ramp of $10{ }^{\circ} \mathrm{C} \mathrm{min}^{-1}$. Finally, $550{ }^{\circ} \mathrm{C}$ is maintained over $60 \mathrm{~min}$.

2.4. Reaction System. The catalytic activity and selectivity of the different catalysts were measured in the vapor phase using an automated Microactivity Effi reactor from PID at low and high pressures. The methanol/water mixture was fed by an HPLC pump and evaporated at $180{ }^{\circ} \mathrm{C}$. The steam to methanol ratio was $1: 1.5$. The vapor stream entered the reactor and passed through the catalyst bed placed inside a tubular 
reactor made of stainless steel 310 at the desired reaction temperature and pressure. Once steady state conditions were achieved, the product stream was sent to a condenser where the unreacted methanol and water were eliminated. The reforming stream was continuously analyzed by gas chromatography. The analysis of the liquid phase allowed the quantification of the conversion, and undesired condensable products formed. The conversion was calculated in terms of methanol consumed, and the selectivity was determined considering the products obtained through the reaction, i.e., $S_{\mathrm{H}_{2}}=\mathrm{mol} \mathrm{m^{-1 }} \mathrm{H}_{2} /\left(\mathrm{mol} \mathrm{min}{ }^{-1} \mathrm{H}_{2}+\mathrm{mol} \mathrm{min}^{-1} \mathrm{CO}_{2}+\mathrm{mol}\right.$

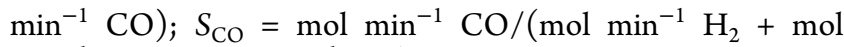
$\left.\mathrm{min}^{-1} \mathrm{CO}_{2}+\mathrm{mol} \mathrm{min}{ }^{-1} \mathrm{CO}\right)$. The carbon mass balance in all the experiments was above $\sim 95 \%$.

\section{RESULTS AND DISCUSSION}

3.1. Steam Reforming of Methanol on Cu Catalysts. 3.1.1. Effect of the Catalyst Support. The catalysts were tested for the methanol steam reforming reaction at $280{ }^{\circ} \mathrm{C}$ using a continuous flow reactor for at least $4 \mathrm{~h}$ (Figure 1). The

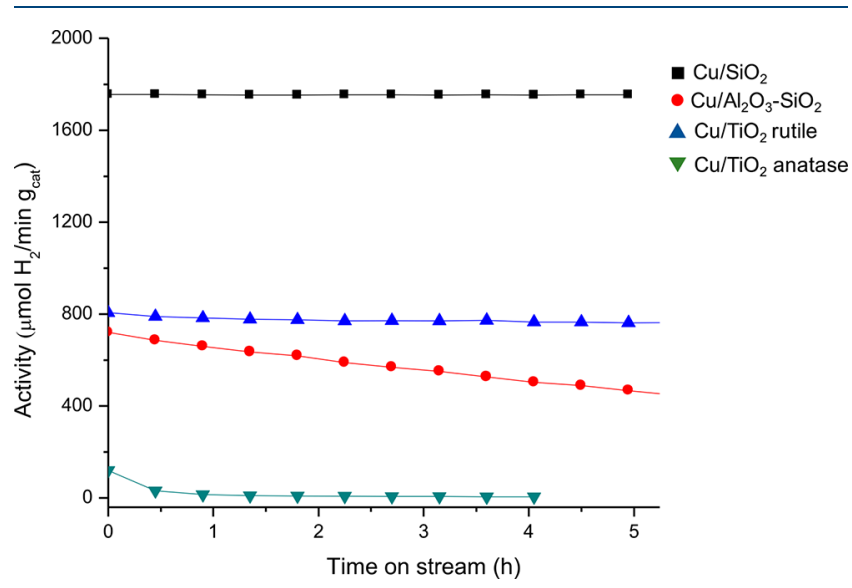

Figure 1. Catalytic activity as a function of time on stream of the different catalysts: $\mathrm{Cu} / \mathrm{SiO}_{2}(\boldsymbol{\square}), \mathrm{Cu} / \mathrm{Al}_{2} \mathrm{O}_{3}-\mathrm{SiO}_{2}(\mathbf{\bullet}), \mathrm{Cu} / \mathrm{TiO}_{2}$ rutile $(\boldsymbol{\Delta})$, and $\mathrm{Cu} / \mathrm{TiO}_{2}$ anatase $(\boldsymbol{\nabla})$ during steam reforming of methanol at atmospheric pressure and $280{ }^{\circ} \mathrm{C}$ and a steam to methanol ratio of 1:1.5. catalytic activity and stability of these materials measured in terms of hydrogen production varied significantly depending on the support employed. For instance, on $\mathrm{Cu} / \mathrm{SiO}_{2}$ the catalytic activity was significantly higher than the rest of the catalysts with values around $1750 \mu \mathrm{mol} \mathrm{H}_{2} \min ^{-1} \mathrm{~g}_{\text {cat }}{ }^{-1}$ at $80 \%$ methanol conversion. While this value was significantly higher than those observed on $\mathrm{Cu}$ supported on $\mathrm{Al}_{2} \mathrm{O}_{3}, \mathrm{TiO}_{2}$ rutile, and $\mathrm{TiO}_{2}$ anatase, the level of conversion was close to the equilibrium (>99\%). Therefore, $\mathrm{Cu}-\mathrm{SiO}_{2}$ true catalytic activity cannot be determined under these conditions. To properly address this issue, additional experiments were performed at lower conversion $(60 \%)$, and the activity under steady state conditions was $\sim 5500 \mu \mathrm{mol} \mathrm{H} \mathrm{min}^{-1} \mathrm{~g}_{\text {cat }}{ }^{-1}$ (see Table S1). Notably, in the case of $\mathrm{Al}_{2} \mathrm{O}_{3}-\mathrm{SiO}_{2}$, the hydrogen production rate started at $\sim 700 \mu \mathrm{mol} \mathrm{H} \mathrm{min}^{-1} \mathrm{~g}_{\mathrm{cat}}{ }^{-1}$ and progressively decreased to $\sim 500 \mu \mathrm{mol} \mathrm{H} \mathrm{min}^{-1} \mathrm{~g}_{\mathrm{cat}}{ }^{-1}$ after $5 \mathrm{~h}$ of reaction. $\mathrm{Cu} / \mathrm{TiO}_{2}$ rutile showed higher productivities than $\mathrm{Cu} / \mathrm{Al}_{2} \mathrm{O}_{3}-$ $\mathrm{SiO}_{2}$ with values of $\sim 800 \mu \mathrm{mol} \mathrm{H} \mathrm{H}_{2} \mathrm{~min}^{-1} \mathrm{~g}_{\text {cat }}{ }^{-1}$.

In terms of stability, $\mathrm{Cu} / \mathrm{TiO}_{2}$ rutile retained its catalytic activity throughout the $5 \mathrm{~h}$ of reaction. In contrast, $\mathrm{Cu} / \mathrm{TiO}_{2}$ anatase showed significant rates of deactivation and low $\mathrm{H}_{2}$ productivity. At the beginning of the reaction, the activity was $180 \mu \mathrm{mol} \mathrm{H}_{2} \min ^{-1} \mathrm{~g}_{\text {cat }}{ }^{-1}$, and after $4 \mathrm{~h}$ of reaction this value decreased to $21.8 \mu \mathrm{mol} \mathrm{H}_{2} \min ^{-1} \mathrm{~g}_{\text {cat }}{ }^{-1}$. As a result, the catalytic activity of the $\mathrm{Cu}$ catalysts followed the following trend $\mathrm{SiO}_{2}>\mathrm{TiO}_{2}$ rutile $>\mathrm{Al}_{2} \mathrm{O}_{3}-\mathrm{SiO}_{2}>\mathrm{TiO}_{2}$ anatase. Furthermore, assessment of the internal mass transport limitations using the Weisz-Prater criterion showed that these catalysts are not affected by intraparticle diffusion limitations (see Table S2).

The average product distribution obtained during the $4-5 \mathrm{~h}$ reaction (Figure 2a) indicated that on $\mathrm{Cu}$ catalysts the formation of light hydrocarbons (methane, ethane, ethylene) was undetectable using GC-FID/TCD; except on $\mathrm{TiO}_{2}$ anatase, small quantities of $\mathrm{CH}_{4}$ were observed $(0.04 \mathrm{~mol} \%$ in wet basis). Furthermore, analyses of the liquid condensate collected after the microreactor step indicated that no oxygenated species were formed during reaction. On $\mathrm{Cu} /$ $\mathrm{SiO}_{2}$ and $\mathrm{Cu} / \mathrm{TiO}_{2}$ rutile catalysts, the $\mathrm{CO}$ concentration was significantly higher $(\sim 0.35$ and $0.2 \mathrm{~mol} \%$, respectively), while in the case of $\mathrm{Cu} / \mathrm{Al}_{2} \mathrm{O}_{3}-\mathrm{SiO}_{2}$ and $\mathrm{Cu} / \mathrm{TiO}_{2}$ anatase only $\sim 0.05 \mathrm{~mol} \%$ was detected (Figure $2 \mathrm{~b}$ ).
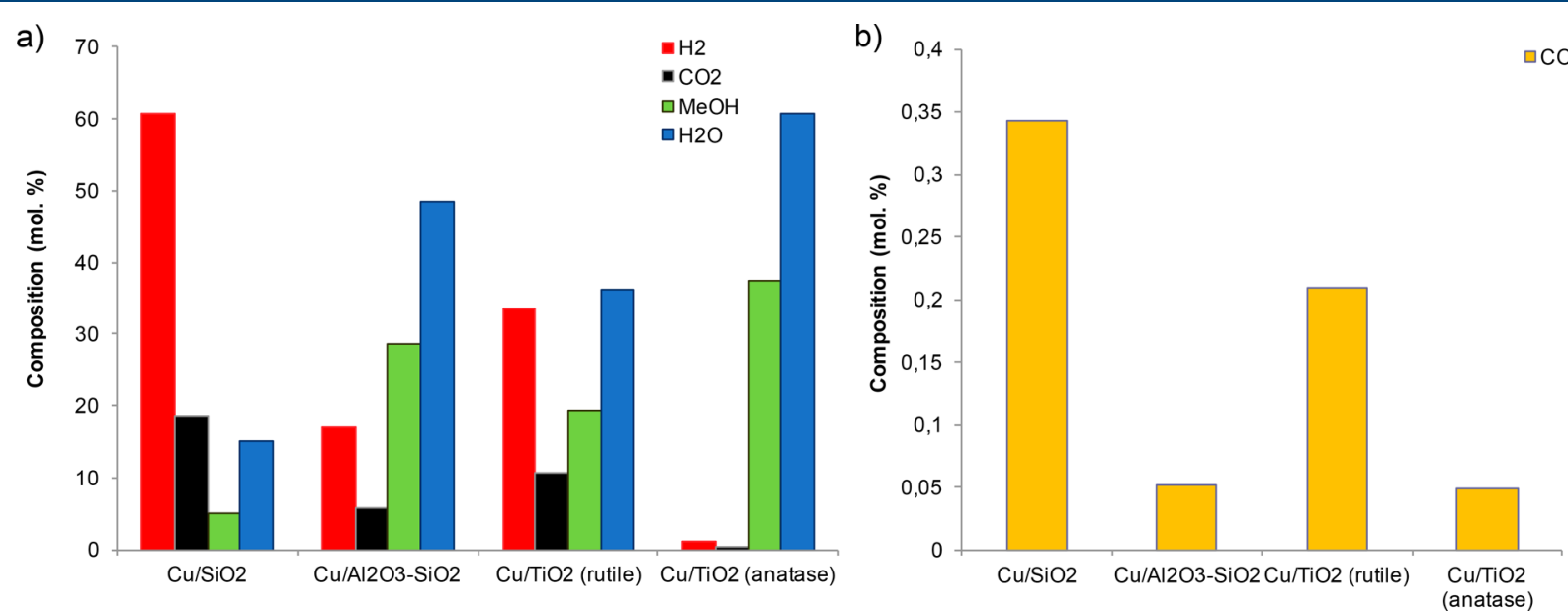

Figure 2. Product distribution (a) and carbon monoxide composition (b) on a wet basis obtained after $4 \mathrm{~h}$ of methanol steam reforming at atmospheric pressure and $280{ }^{\circ} \mathrm{C}$ for $\mathrm{Cu} / \mathrm{SiO}_{2}, \mathrm{Cu} / \mathrm{Al}_{2} \mathrm{O}_{3}-\mathrm{SiO}_{2}, \mathrm{Cu} / \mathrm{TiO}_{2}$ rutile, and $\mathrm{Cu} / \mathrm{TiO}_{2}$ anatase at a W/F of $1200 \mathrm{~kg} / \mathrm{L} \mathrm{h}{ }^{-1}$. 
In terms of selectivity, however, $\mathrm{Cu} / \mathrm{TiO}_{2}$ anatase showed the highest $\mathrm{CO}$ and $\mathrm{CH}_{4}$ selectivity with values of 2.3 and $2 \%$, respectively (see Table $\mathrm{S} 3$ ). In contrast, $\mathrm{Cu}$ supported on $\mathrm{SiO}_{2}$, $\mathrm{Al}_{2} \mathrm{O}_{3}-\mathrm{SiO}_{2}$, and $\mathrm{TiO}_{2}$ rutile resulted in $\mathrm{CO}$ selectivity below $0.5 \%$ and negligible $\mathrm{CH}_{4}$ amounts at similar levels of conversion. The ratio of $\mathrm{CO}_{2}$ to $\mathrm{CO}$ and $\mathrm{H}_{2}$ to $\mathrm{CO}_{2}$ are good indicators of the contributions of the methanol reforming reaction, methanol decomposition, and coke formation. ${ }^{3,4}$ For instance, on $\mathrm{Cu}$ supported on $\mathrm{SiO}_{2}, \mathrm{Al}_{2} \mathrm{O}_{3}-\mathrm{SiO}_{2}$, and $\mathrm{TiO}_{2}$ rutile, similar ratios of $\mathrm{H}_{2} / \mathrm{CO}_{2}$ were obtained with values ranging from 3.1 to 3.3. In contrast, $\mathrm{Cu} / \mathrm{TiO}_{2}$ anatase showed a $\mathrm{H}_{2} / \mathrm{CO}_{2}$ ratio above 3.5 . The higher ratio of hydrogen to carbon dioxide on $\mathrm{Cu} / \mathrm{TiO}_{2}$ anatase could be associated with higher rates of methanol decomposition or other parallel pathways that can generate hydrogen (e.g., coke deposition and dehydrogenation). At the same time, the $\mathrm{CO}_{2} / \mathrm{CO}$ ratio value was 7.40, which is significantly lower than that obtained on $\mathrm{SiO}_{2}$ (231), $\mathrm{Al}_{2} \mathrm{O}_{3}-\mathrm{SiO}_{2}$ (87), and $\mathrm{TiO}_{2}$ rutile (47) catalysts. The low catalytic activity and poor stability and selectivity of $\mathrm{Cu} / \mathrm{TiO}_{2}$ anatase compared to rutile could be associated with the differences in the Lewis acidity of partially uncoordinated $\mathrm{Ti}^{4+}$ cations, which in turn affects the interaction of polar molecules with the surface. ${ }^{46-48}$

3.1.2. Effect of $W / F$, Temperature, and Pressure on $\mathrm{Cu} /$ $\mathrm{SiO}_{2}$ Performance. To further explore the stability, selectivity, and activity of the $\mathrm{Cu} / \mathrm{SiO}_{2}$ catalyst, we decided to investigate the product distribution as a function of the catalyst to feed ratio and time on stream (TOS) at low and high temperatures $\left(260-280{ }^{\circ} \mathrm{C}\right.$ ) and pressures ( 1 and 25 bar). As shown in Figure 3, increasing temperature enhanced the activity; however, as the conversion approached the equilibrium ( $90 \%)$, this effect was attenuated. Notably, the ratio of $\mathrm{H}_{2}$ to $\mathrm{CO}_{2}$ increased from 3.32 to 3.64 when the temperature was increased from 260 to $300{ }^{\circ} \mathrm{C}$. The opposite trend was observed on the $\mathrm{CO}$ to $\mathrm{CO}_{2}$ ratio (see Table S4). This ratio drastically decreased from 153 to 45 with temperature. These trends could be attributed to a combination of different factors, including (1) changes in the relative kinetics of methanol decomposition (reaction 2) and reforming reaction (reaction 1 ), (2) differences in surface coverage as the conversion increases, and (3) surface reconstruction accompanied by $\mathrm{Cu}$ sintering. ${ }^{26}$ Due to the high conversions reached under these reaction conditions, it was not possible to assess the activation energies. This issue will be addressed in future studies in our group.

The stability of the catalyst was studied under four different reaction conditions over the course of $\sim 20 \mathrm{~h}$, in which catalystto-feed ratio (W/F) was varied from 300 to $600 \mathrm{~kg} /\left(\mathrm{L} \mathrm{s}^{-1}\right)$ at reaction temperatures ranging from 260 to $300{ }^{\circ} \mathrm{C}$ and atmospheric pressure (Figure S1). Initially, the catalyst was operated at an intermediate W/F of $300 \mathrm{~kg} /\left(\mathrm{L} \mathrm{s}^{-1}\right)$ and 260 ${ }^{\circ} \mathrm{C}$ for $4 \mathrm{~h}$ reaching a conversion of $56 \%$ and high selectivity for $\mathrm{CO}_{2}$ and $\mathrm{H}_{2}$ with no apparent changes over the course of the reaction. The catalyst showed no sign of deactivation even at high temperatures. Further studies at high and low pressures were performed to determine the stability of the catalyst and selectivity under harsh reaction environments. The results showed that in the case $\mathrm{Cu} / \mathrm{SiO}_{2}$ the conversion and product distributions remained constant over the TOS explored at low and high pressures (Figure 4). However, the conversion and products concentration at high pressure were reduced compared to those obtained at low pressure. This change in activity was accompanied by a change in selectivity. The CO
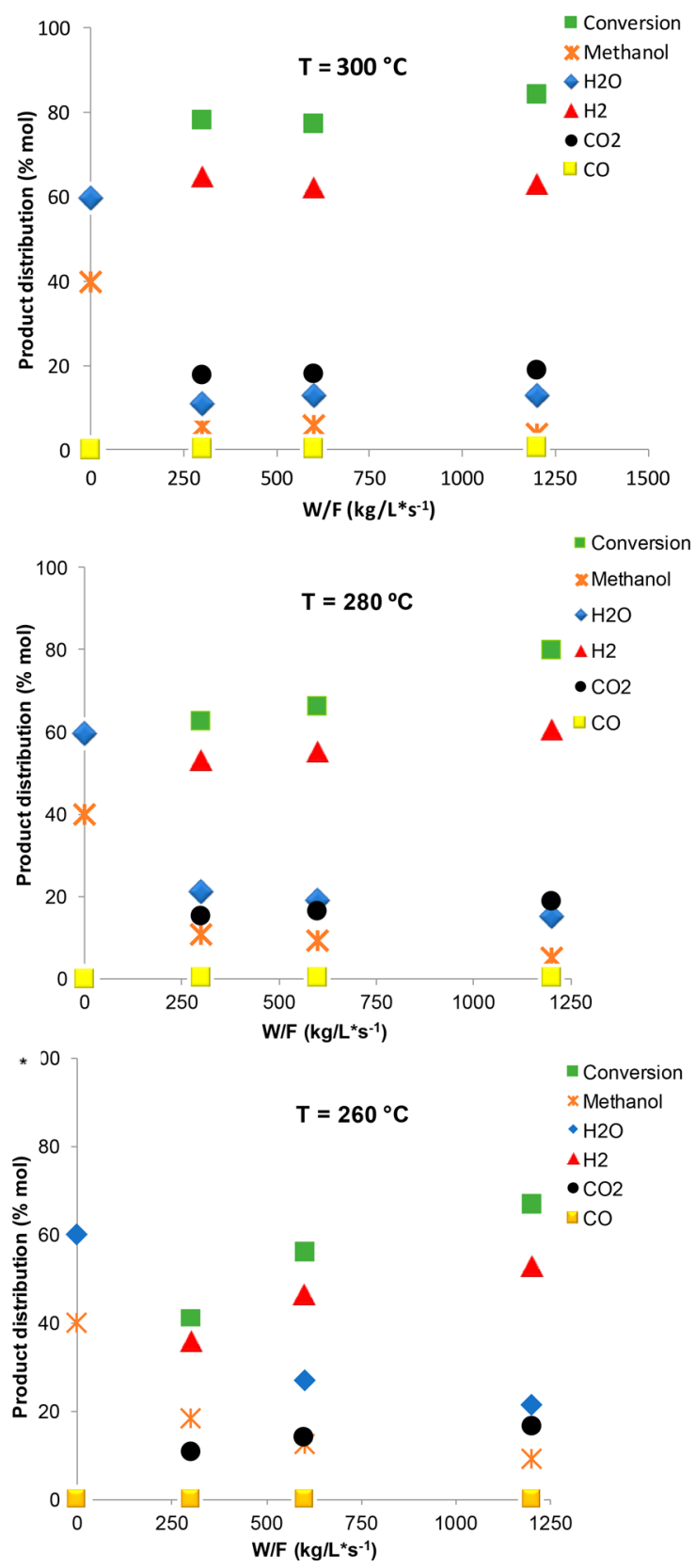

Figure 3. Product distribution on a wet basis as a function of W/F obtained during methanol steam reforming at atmospheric pressure on $\mathrm{Cu} / \mathrm{SiO}_{2}$ at different W/F $\left(300-1200 \mathrm{~kg}\right.$ of catalyst $\left./ \mathrm{L} \cdot \mathrm{s}^{-1}\right)$ and temperatures $\left(260-300{ }^{\circ} \mathrm{C}\right)$.

concentration was $0.3 \mathrm{~mol} \%$ at low pressures (TOS ranging 10 to $80 \mathrm{~h}$ ), while in the high pressure tests this value was nearly 3 -fold higher $(\sim 0.9 \mathrm{~mol} \%)$. One could imagine that as pressure increases, capillary condensation inside the porous structure of the catalyst is favored. ${ }^{49}$ The liquid layer could create additional limitations to the mass transport of molecules or solvate kinetically relevant reaction intermediates. ${ }^{50-53}$ In turn, the reaction kinetics are attenuated. In addition, it could be possible that upon formation of liquid inside the porous structure, the $\mathrm{Cu}$ catalyst surface is modified or reconstructed, hindering the formation of the surface formate $(-\mathrm{HCOOH})$ via $\eta^{1}(\mathrm{O})$-binding, which is believed to be the precursor of $\mathrm{CO}_{2}$ and hydrogen in methanol reforming on oxophilic catalytic surfaces (e.g., $\mathrm{Cu}$ ). 


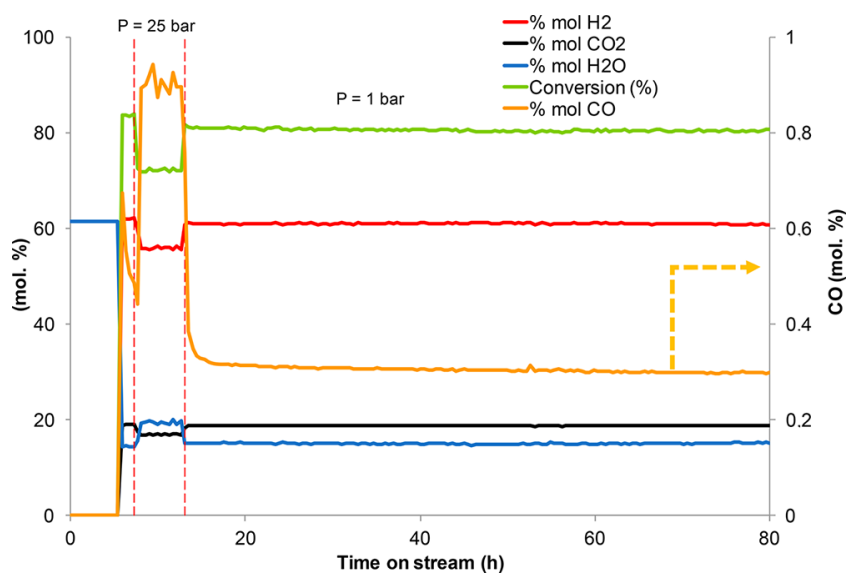

Figure 4. Product distribution on a wet basis as a function of time on stream (TOS) obtained during methanol steam reforming at atmospheric pressure and $25 \mathrm{bar}$ at $280{ }^{\circ} \mathrm{C}$ on $\mathrm{Cu} / \mathrm{SiO}_{2}$ at different $\mathrm{W} / \mathrm{F}\left(1200 \mathrm{~kg}\right.$ of catalyst/L h $\left.\mathrm{h}^{-1}\right)$.

Here, it is important to remember that at high conversions it is not possible to determine the stability of a catalyst solely based on the TOS profile as an excess of catalyst will mask the deactivation. For this reason, postreaction characterization was performed to determine the extent of catalyst sintering and coke deposition (see section 3.2).

3.2. Catalysts Characterization. 3.2.1. Reducibility and Acidity. To interpret the differences in activity and selectivity observed, we decided to characterize the reducibility and acidity of these catalysts by temperature-programmed reduction (TPR) and temperature-programmed desorption of ammonia (TPD- $\mathrm{NH}_{3}$ ). As shown in Figure 5, $\mathrm{SiO}_{2}$ and $\mathrm{Al}_{2} \mathrm{O}_{3}-\mathrm{SiO}_{2}$ showed a symmetric peak centered at 275 and $256{ }^{\circ} \mathrm{C}$, respectively (see Figure $5 \mathrm{a}, \mathrm{b}$ ). This reduction peak was assigned to the reduction of $\mathrm{Cu}^{2+}$ to $\mathrm{Cu}^{026}$. In contrast, a more complex fingerprint of $\mathrm{Cu}$ reduction was observed on $\mathrm{TiO}_{2}$ rutile and anatase (Figure $5 \mathrm{c}, \mathrm{d}$ ). The $\mathrm{Cu}$ supported on a $\mathrm{TiO}_{2}$ rutile catalyst was reduced between 90 and $215{ }^{\circ} \mathrm{C}$ with a maximum at $184{ }^{\circ} \mathrm{C}$, while on $\mathrm{TiO}_{2}$ anatase, the $\mathrm{Cu}$ reduction started at higher temperatures $\left(\sim 120^{\circ} \mathrm{C}\right)$ with its maximum centered at $193{ }^{\circ} \mathrm{C}$. As shown in Table S5, the extent of reduction for the four catalysts was similar (90 to 98\%), indicating that reduction can be accomplished at lower temperatures than those reported for bulk $\mathrm{Cu}$ (350-500 $\left.{ }^{\circ} \mathrm{C}\right) .{ }^{28}$

To further understand the differences between the four catalysts, the TPR profiles were deconvoluted and quantified using a Gaussian fitting model. In Figure 5c,d, the TPR profile was fitted using three Gaussian curves centered at approximately 135,180 , and $195{ }^{\circ} \mathrm{C}$, for $\mathrm{Cu}$ on $\mathrm{TiO}_{2}$ rutile and anatase (distribution plot in Figure S2). The results indicated that on $\mathrm{TiO}_{2}$ anatase the major contribution to the hydrogen consumption took place at around $195-200{ }^{\circ} \mathrm{C}$, while in the case of $\mathrm{TiO}_{2}$ rutile the reduction occurred at the lower temperature ranges of $130-135{ }^{\circ} \mathrm{C}$ and $180-185{ }^{\circ} \mathrm{C}$ (see Figure 5d). The higher reducibility of $\mathrm{Cu}$ on $\mathrm{TiO}_{2}$ rutile and anatase could be attributed to metal-support interactions, which can alter the electronic properties of the $\mathrm{Cu}$ surface. $^{54-56}$ The lower reduction temperatures of $\mathrm{Cu}$ supported on $\mathrm{TiO}_{2}$ rutile could be attributed to a higher degree of metal dispersion. ${ }^{57,58}$ In contrast, on nonreducible metal oxides (e.g., $\mathrm{SiO}_{2}$ and $\mathrm{Al}_{2} \mathrm{O}_{3}-\mathrm{SiO}_{2}$ ), all the $\mathrm{Cu}$ clusters

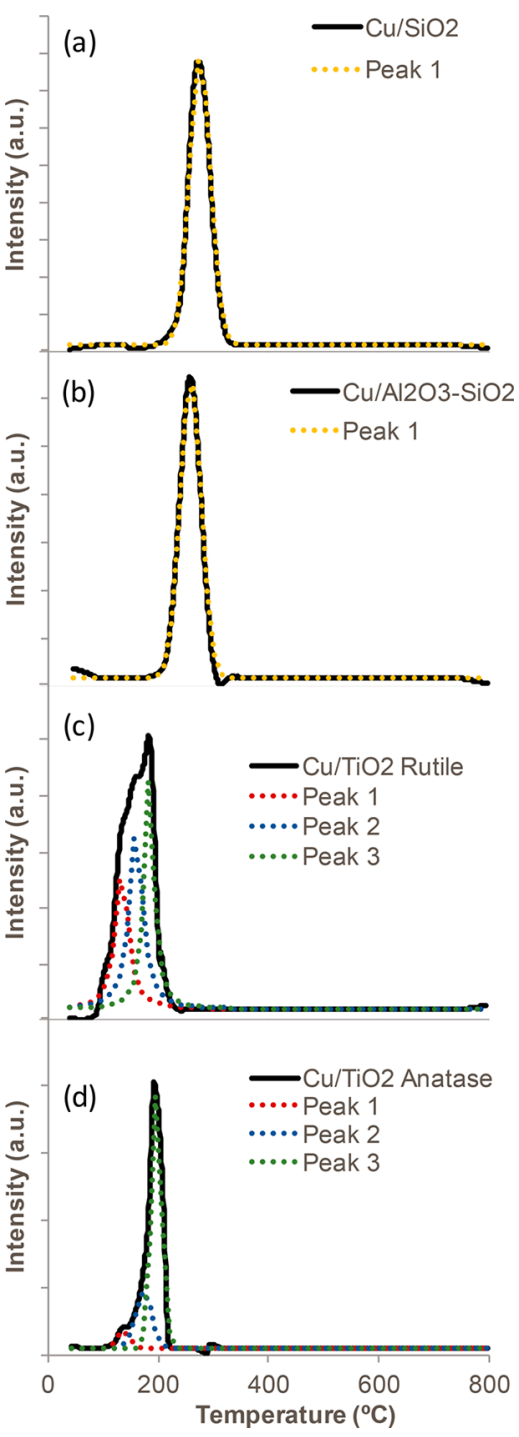

Figure 5. Temperature-programmed reduction of the $\mathrm{Cu} / \mathrm{SiO}_{2}(\mathrm{a})$, $\mathrm{Cu} / \mathrm{Al}_{2} \mathrm{O}_{3}-\mathrm{SiO}_{2}$ (b), $\mathrm{Cu} / \mathrm{TiO}_{2}$ rutile (c), $\mathrm{Cu} / \mathrm{TiO}_{2}$ anatase (d) catalysts.

were reduced at higher temperatures and in a narrow temperature range $\left(260-270{ }^{\circ} \mathrm{C}\right)$.

TPD- $\mathrm{NH}_{3}$ analyses were performed to measure the catalyst acidity (Figure 6). The desorption of $\mathrm{NH}_{3}$ on $\mathrm{SiO}_{2}$ and $\mathrm{Al}_{2} \mathrm{O}_{3}-\mathrm{SiO}_{2}$ started at mild temperatures $\left(\sim 38{ }^{\circ} \mathrm{C}\right)$ and finished at 340 and $458{ }^{\circ} \mathrm{C}$, respectively. On $\mathrm{Cu} / \mathrm{SiO}_{2}$, two desorption peaks were observed at 70 and $340{ }^{\circ} \mathrm{C}$. In the case of $\mathrm{Cu} / \mathrm{Al}_{2} \mathrm{O}_{3}-\mathrm{SiO}_{2}$, two broad desorption peaks were observed, the first one at $80{ }^{\circ} \mathrm{C}$ and the second one at 290 ${ }^{\circ} \mathrm{C}$. In contrast, in $\mathrm{Cu} / \mathrm{TiO}_{2}$-supported catalysts the amount of $\mathrm{NH}_{3}$ desorbed was negligible. In the case of $\mathrm{Cu} / \mathrm{TiO}_{2}$ anatase, a broad peak was observed in the low temperature range (68$\left.142{ }^{\circ} \mathrm{C}\right)$. Similarly, on $\mathrm{Cu} / \mathrm{TiO}_{2}$ rutile the desorption extended from 78 to $170{ }^{\circ} \mathrm{C}$. While it is tempting to associate the desorption temperatures to the surface-adsorbate interactions, the studies published by Prof. R. Gorte demonstrated that the possible interference of other phenomena (e.g., mass transport limitations and adsorbate-adsorbate interactions) hinders the utilization of this technique to obtain energetic parameters. $^{59-62}$ As a result, it is not possible to obtain valid conclusions regarding strength of the acid sites on the 


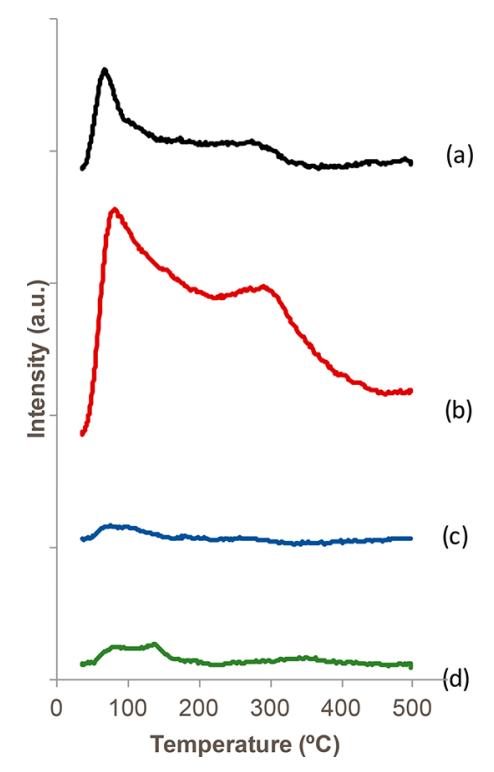

Figure 6. Temperature-programmed desorption of ammonia (TPD$\mathrm{NH}_{3}$ ) fingerprints for the $\mathrm{Cu} / \mathrm{SiO}_{2}(\mathrm{a}), \mathrm{Cu} / \mathrm{Al}_{2} \mathrm{O}_{3}-\mathrm{SiO}_{2}$ (b), $\mathrm{Cu}$ / $\mathrm{TiO}_{2}$ rutile (c), $\mathrm{Cu} / \mathrm{TiO}_{2}$ anatase $(\mathrm{d})$ catalysts.

materials herein studied. Instead, the total acid site density has been calculated (see Table 2).

Table 2. Acid Site Density of the Different Catalysts Obtained from Temperature Programmed Desorption of Ammonia ( $\mathrm{NH}_{3}$-TPD)

\begin{tabular}{lrc}
\multicolumn{1}{c}{ catalysts } & $\begin{array}{r}\text { acid site density }(\mu \mathrm{mol} \\
\left.\mathrm{g}^{-1}\right)\end{array}$ & $\begin{array}{c}\text { acid site density }(\mu \mathrm{mol} \\
\left.\mathrm{m}^{-2}\right)\end{array}$ \\
$\mathrm{Cu} / \mathrm{SiO}_{2}$ & 503.9 & 2.2 \\
$\mathrm{Cu} / \mathrm{Al}_{2} \mathrm{O}_{3}-\mathrm{SiO}_{2}$ & 1871.1 & 6.7 \\
$\mathrm{Cu} / \mathrm{TiO}_{2}$ rutile & 17.6 & 1.8 \\
$\mathrm{Cu} / \mathrm{TiO}_{2}$ anatase & 33.2 & 3.3 \\
\hline
\end{tabular}

The concentration of acid sites on $\mathrm{TiO}_{2}$ rutile and anatase was rather small. One would expect the metal- $\mathrm{TiO}_{2}$ catalysts to have a higher concentration of acid sites. For instance, Aranda et al. $^{63}$ reported that on $\mathrm{Ru}$ supported $\mathrm{TiO}_{2}$ catalysts, the surface acid site concentrations varied from 312 to $551 \mu \mathrm{mol}$ $\mathrm{NH}_{3} \mathrm{~g}_{\text {cat }}{ }^{-1}$. However, in that case, the interaction of $\mathrm{Ru}$ clusters with the support facilitated the reduction of the $\mathrm{Ti}^{4+}$ to $\mathrm{Ti}^{3+}$ cations. These oxygen vacancies effectively bound ammonia to the catalyst surface, resulting in a higher surface concentration of acid sites. Similar results have been published by Pham et al. on $\mathrm{Ru} / \mathrm{TiO}_{2} / \mathrm{C}$ for the decarboxylative ketonization of organic acids in the liquid phase. ${ }^{64}$ In the case of $\mathrm{Cu} / \mathrm{TiO}_{2}$, the extent of support $\left(\mathrm{TiO}_{2}\right)$ reduction was negligible, as shown by TPR measurements (Table S5), explaining the lower concentration of surface acid sites or $\mathrm{Ti}^{\delta+}$ uncoordinated cations. As expected, the highest concentration of acid sites per gram of catalyst was observed on $\mathrm{Cu} / \mathrm{Al}_{2} \mathrm{O}_{3}-\mathrm{SiO}_{2}$. On this catalyst, the primary source of acidity comes from the $\mathrm{Si}-\mathrm{O}-\mathrm{Al}$ bridging sites, where the charge unbalance between $\mathrm{Si}^{4+}$ and $\mathrm{Al}^{3+}$ creates an acid site. In the dehydrated state, the $\mathrm{Al}^{3+}$ cations bonded to three oxygens have an electron-pair vacancy that can be filled by sharing an electron pair with a base, i.e., Lewis acid sites. In the presence of water, the $\mathrm{Al}$ cations serve as electron acceptors of one free-electron of oxygen in $\mathrm{H}_{2} \mathrm{O}$ leaving an ionizable proton available for reaction, i.e., Brønsted acid sites. ${ }^{65,66}$ At the reaction conditions herein employed, the high concentration of vapor water facilitates the formation of Brønsted acid sites on the catalyst surface. These sites can accelerate the formation of unsaturated species that can polymerize on the surface deactivating the $\mathrm{Cu}$ clusters, explaining the fast rate of catalyst deactivation observed on $\mathrm{Cu} / \mathrm{Al}_{2} \mathrm{O}_{3}-\mathrm{SiO}_{2}$ catalysts.

Notably, on $\mathrm{SiO}_{2}$, the stability and catalytic activity were not affected by the presence of a small concentration of acid sites. To rationalize these results, it is important to consider the reaction mechanism behind the steam reforming reaction of methanol. Detailed kinetic analysis of methanol steam reforming on $\mathrm{Cu}, \mathrm{Pd}, \mathrm{Pt}, \mathrm{Ni}$, and $\mathrm{Rh}$ supported on $\mathrm{SiO}_{2}$ has shown that on $\mathrm{Cu}$ surfaces the reaction mechanism is drastically different, when compared to the other metals. ${ }^{12,13,67}$ According to Takezawa and Iwasa, the methanol reforming reaction on $\mathrm{Cu}$ starts with the dehydrogenation of $\mathrm{CH}_{3} \mathrm{OH}$ to $\mathrm{HCHO}$. This surface aldehyde is attacked by nucleophilic addition of $-\mathrm{OH}$ or $\mathrm{H}_{2} \mathrm{O}$ to produce a $\mathrm{HCOOH}$ species that easily decomposes into $\mathrm{CO}_{2}$ and $\mathrm{H}_{2}$. Surface science studies have shown that aldehydes adsorb on IB metals (e.g., $\mathrm{Cu}$ and $\mathrm{Ag})$ preferentially via $\eta^{1}(\mathrm{O})$-structure. In this configuration, the molecular identity of the $\mathrm{C}-\mathrm{O}$ bond is retained, which facilitates the nucleophilic attack of $-\mathrm{OH}$ surface species. This mechanism is very different from that observed on group VIII metals, where $\eta^{2}(\mathrm{CO})$ binding is more favorable and decomposition of methanol to $\mathrm{CO}$ and $\mathrm{H}_{2}$ is enhanced. Sagar et al. ${ }^{57}$ showed that moderate and weak acidic sites of $\mathrm{Al}_{2} \mathrm{O}_{3}-\mathrm{ZrO}_{2}$ were beneficial for the dehydrogenation of cyclohexanol. One can envision that on $\mathrm{Cu} / \mathrm{SiO}_{2}$ the lower concentration and weaker acid sites favored the stability of the catalyst compared to $\mathrm{Al}_{2} \mathrm{O}_{3}-\mathrm{SiO}_{2}$, where the formation of unsaturated oxygenates accelerated carbon deposition on $\mathrm{Cu}$ and pore blockage.

3.3. Assessment of the Catalyst Deactivation. 3.3.1. Thermal Gravimetric Analysis (TGA). Thermal gravimetric analysis of the catalysts after reaction was performed to determine the concentration and type of carbon deposits after reaction. It is worth mentioning that in the case of $\mathrm{Cu} / \mathrm{SiO}_{2}$ the analysis was performed after $20 \mathrm{~h}$ of continuous reaction, while the rest of the catalysts were analyzed after $5 \mathrm{~h}$ of reaction. As shown in Figure 7, all the samples, except for $\mathrm{Cu} /$ $\mathrm{Al}_{2} \mathrm{O}_{3}-\mathrm{SiO}_{2}$, showed a net growth of mass, which could be a consequence of the oxidation of metallic copper to $\mathrm{CuO}$. This oxidation can be clearly observed in the sample $\mathrm{Cu} / \mathrm{TiO}_{2}$ anatase, where a two-step mass growth was evident. The first step was associated with the oxidation from $\mathrm{Cu}$ to $\mathrm{Cu}_{2} \mathrm{O}$, and the second one was due to the step $\mathrm{Cu}_{2} \mathrm{O}$ to $\mathrm{CuO}$. The theoretical total mass increase was $5 \%$. This value was reached only in the $\mathrm{Cu} / \mathrm{TiO}_{2}$ anatase. Notably, on $\mathrm{Cu} / \mathrm{SiO}_{2}$ and $\mathrm{Cu}$ / $\mathrm{TiO}_{2}$ rutile mass growth was $4.2 \%$ and $2.8 \%$, respectively. The differences between experimental and theoretical mass increase could be caused by diffusional limitations of air inside the catalyst particles, originated by a partial collapse of the support (especially in $\mathrm{TiO}_{2}$ rutile) or due to a simultaneous copper oxidation and coke elimination. The sharp mass loss observed on $\mathrm{Cu} / \mathrm{SiO}_{2}$ could be attributed to this process. The presence of carbon residues was more prominent in $\mathrm{Cu} / \mathrm{Al}_{2} \mathrm{O}_{3}-\mathrm{SiO}_{2}$ where the decrease of the mass was constant $(\sim 7 \%)$. The carbon content for each sample was estimated assuming that during the TGA analysis (a) all the $\mathrm{Cu}$ metal (i.e., 20\%) was oxidized to $\mathrm{CuO}$, leading to a theoretical weight gain of $5.03 \%$, and (b) all the carbon deposits were oxidized to $\mathrm{CO}_{2}$ and $\mathrm{H}_{2} \mathrm{O}$. The results of this analysis are summarized in Table S6. Here, 


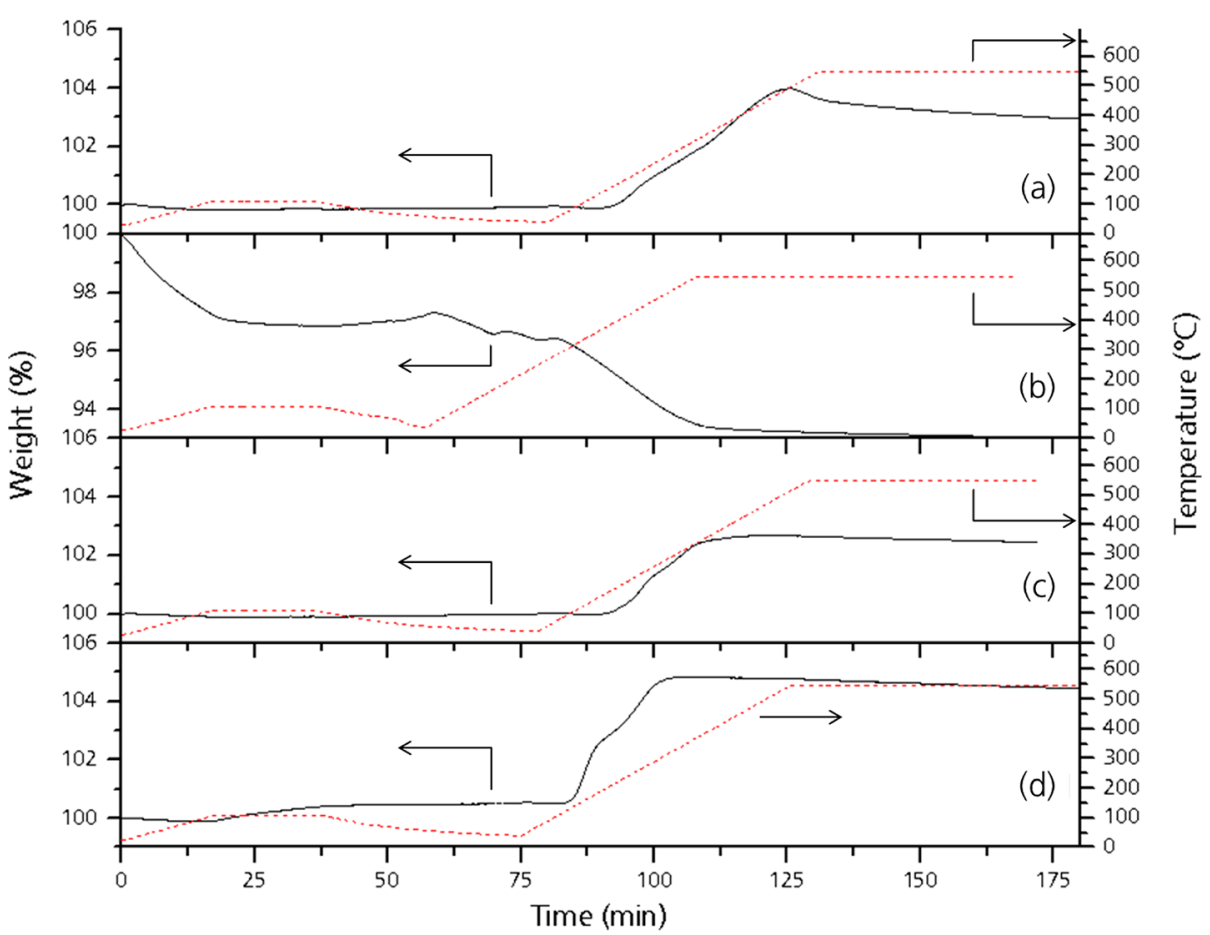

Figure 7. Thermal gravimetric analyses of the different catalysts after $5 \mathrm{~h}\left(20 \mathrm{~h}\right.$ for $\left.\mathrm{Cu} / \mathrm{SiO}_{2}\right)$ of a steam reforming reaction at atmospheric pressure and $280{ }^{\circ} \mathrm{C}$ using an aqueous solution of methanol $(13.4 \mathrm{M})$. The samples analyzed were $\mathrm{Cu} / \mathrm{SiO}_{2}(\mathrm{a}), \mathrm{Cu} / \mathrm{Al}_{2} \mathrm{O}_{3}-\mathrm{SiO}_{2}$ (b), $\mathrm{Cu} / \mathrm{TiO} \mathrm{O}_{2} \mathrm{rutile}(\mathrm{c})$, and $\mathrm{Cu} / \mathrm{TiO}_{2}$ anatase (d). The weight evolution is presented in a continuous line (left axis) and the temperature in a dashed line (right axis).

it can be noted that carbon content reached the highest value on $\mathrm{Cu} / \mathrm{Al}_{2} \mathrm{O}_{3}-\mathrm{SiO}_{2}(\sim 12 \%)$. In this sample, the fast mass losses at the beginning of the experiment could be attributed to the presence of volatile species absorbed and carbon deposits.

In a recent review, it was highlighted that methanol can undergo $\mathrm{C}-\mathrm{C}$ bond coupling to form unsaturated hydrocarbons (i.e., methanol to olefins) in the presence of acid sites, disproving previous studies that suggested that these $\mathrm{C}-\mathrm{C}$ couplings during the methanol to olefins process was due to small impurities in the feed. ${ }^{68}$ Although the reaction temperatures herein employed are relatively lower than in the case of the methanol to olefins process, the surface reaction intermediates are the same (i.e., surface formate). This intermediate can either decompose to $\mathrm{H}_{2}$ and $\mathrm{CO}_{2}$ on a metallic $\mathrm{Cu}$ site ${ }^{12,13,67}$ or undergo $\mathrm{C}-\mathrm{C}$ coupling to form unsaturated hydrocarbons on an acid site. This surface formate is also reported to be responsible for the high selectivity to $\mathrm{H}_{2}$ and $\mathrm{CO}_{2}$ on $\mathrm{Cu}$ catalysts. ${ }^{68}$ Thus, it is possible that the higher acidity of the $\mathrm{Cu} / \mathrm{Al}_{2} \mathrm{O}_{3}-\mathrm{SiO}_{2}$ catalyst is responsible for the fast rates of deactivation and large carbon deposits (see Table $\mathrm{S} 7$ ). In contrast, on $\mathrm{Cu} / \mathrm{SiO}_{2}$ the acid sites did not activate $\mathrm{C}-$ $\mathrm{C}$ coupling reactions. This is even more relevant if one considers that, in the case of $\mathrm{Cu}$ supported on $\mathrm{SiO}_{2}$, the reaction experiments were performed for $20 \mathrm{~h}$ and temperatures ranging from 260 to $300{ }^{\circ} \mathrm{C}$.

3.3.2. Textural and Microstructure Characterization $\left(\mathrm{N}_{2}\right.$ Physisorption, XRD, HR-TEM). Detailed characterization by $\mathrm{N}_{2}$ physisorption, XRD, and HRTEM was performed to further understand the differences in catalytic activity and stability for the methanol steam reforming reaction. As shown in Figure $\mathrm{S} 4 \mathrm{a}$, all the samples showed a type IV adsorption curve. $\mathrm{Cu}$ / $\mathrm{SiO}_{2}$ and $\mathrm{Cu} / \mathrm{Al}_{2} \mathrm{O}_{3}-\mathrm{SiO}_{2}$ showed the presence of desorption hysteresis caused by the presence of meso-porosity in the system. In contrast, in the $\mathrm{Cu} / \mathrm{TiO}_{2}$ anatase and rutile catalysts, the hysteresis process is less pronounced. As shown by $\mathrm{BJH}$ analysis of the data (Figure $\mathrm{S} 4 \mathrm{~b}$ ), all the materials were meso- and macroporous. In the case of the $\mathrm{Cu} / \mathrm{SiO}_{2}$ catalyst, the pore size distribution was narrower, and the maximum of the distribution was centered at $\sim 320 \AA$. In contrast, on $\mathrm{Cu}$ / $\mathrm{Al}_{2} \mathrm{O}_{3}-\mathrm{SiO}_{2}$ the distribution of pore sizes was wider and centered at $\sim 71 \AA$. As a result, the average pore size, determined by Brunauer-Emmett-Teller (BET) theory, was larger on $\mathrm{Cu} / \mathrm{SiO}_{2}$ (see Table 3). On $\mathrm{TiO}_{2}$ rutile and anatase, the pore size distributions were wider, and the maxima of the peaks were centered at $\sim 400$ and $\sim 700 \AA$, respectively.

Table 3. Surface Area, Micro- and Mesoporous Area, Ratio Meso- to Microporous Area, and Average Pore Size of $\mathrm{Cu}$ / $\mathrm{SiO}_{2}, \mathrm{Cu} / \mathrm{Al}_{2} \mathrm{O}_{3}-\mathrm{SiO}_{2}, \mathrm{Cu} / \mathrm{TiO}_{2}$ Rutile, $\mathrm{Cu} / \mathrm{TiO}_{2}$ Anatase before (BR) and after Reaction (AR)

\begin{tabular}{cccccc}
\multicolumn{1}{c}{ catalysts } & $\begin{array}{c}\text { surface } \\
\text { area } \\
\left(\mathrm{m}^{2} \mathrm{~g}^{-1}\right)\end{array}$ & $\begin{array}{c}\text { microporous } \\
\text { area }\left(\mathrm{m}^{2} \mathrm{~g}^{-1}\right)\end{array}$ & $\begin{array}{c}\text { average } \\
\text { mesoporous } \\
\text { area }\left(2 \mathrm{~g}^{-1}\right)\end{array}$ & $\begin{array}{c}\text { pore size } \\
(\AA)\end{array}$ \\
$\mathrm{Cu} / \mathrm{SiO}_{2}$ & $\mathrm{BR}$ & 228 & 8 & 220 & 188 \\
& $\mathrm{AR}$ & 223 & 1 & 222 & 195 \\
$\mathrm{Cu} / \mathrm{SiO}_{2}-$ & $\mathrm{BR}$ & 279 & 21 & 258 & 115 \\
$\mathrm{Al}_{2} \mathrm{O}_{3}$ & $\mathrm{AR}$ & 214 & 7 & 207 & 124 \\
$\mathrm{Cu} / \mathrm{TiO}_{2}$ & $\mathrm{BR}$ & 10 & 0.8 & 9 & 138 \\
$(\mathrm{rutile})$ & $\mathrm{AR}$ & 11 & 0.9 & 10 & 155 \\
$\mathrm{Cu} / \mathrm{TiO}_{2}$ & $\mathrm{BR}$ & 10 & 1.1 & 9 & 233 \\
$($ anatase $)$ & $\mathrm{AR}$ & 16 & 0.5 & 15 & 219 \\
\hline
\end{tabular}

Notably, after reaction the relative saturation pressure for all the catalysts is lower, indicating a decrease in the $\mathrm{N}_{2}$-accessible surface. As shown in Table 3, the changes in surface area of $\mathrm{Cu} / \mathrm{SiO}_{2}$ and $\mathrm{Cu} / \mathrm{Al}_{2} \mathrm{O}_{3}-\mathrm{SiO}_{2}$ were more pronounced than those observed on $\mathrm{Cu} / \mathrm{TiO}_{2}$ anatase and rutile. The initial surface areas of $\mathrm{Cu} / \mathrm{SiO}_{2}\left(228 \mathrm{~m}^{2} \mathrm{~g}^{-1}\right)$ and $\mathrm{Cu} / \mathrm{Al}_{2} \mathrm{O}_{3}-\mathrm{SiO}_{2}$ 

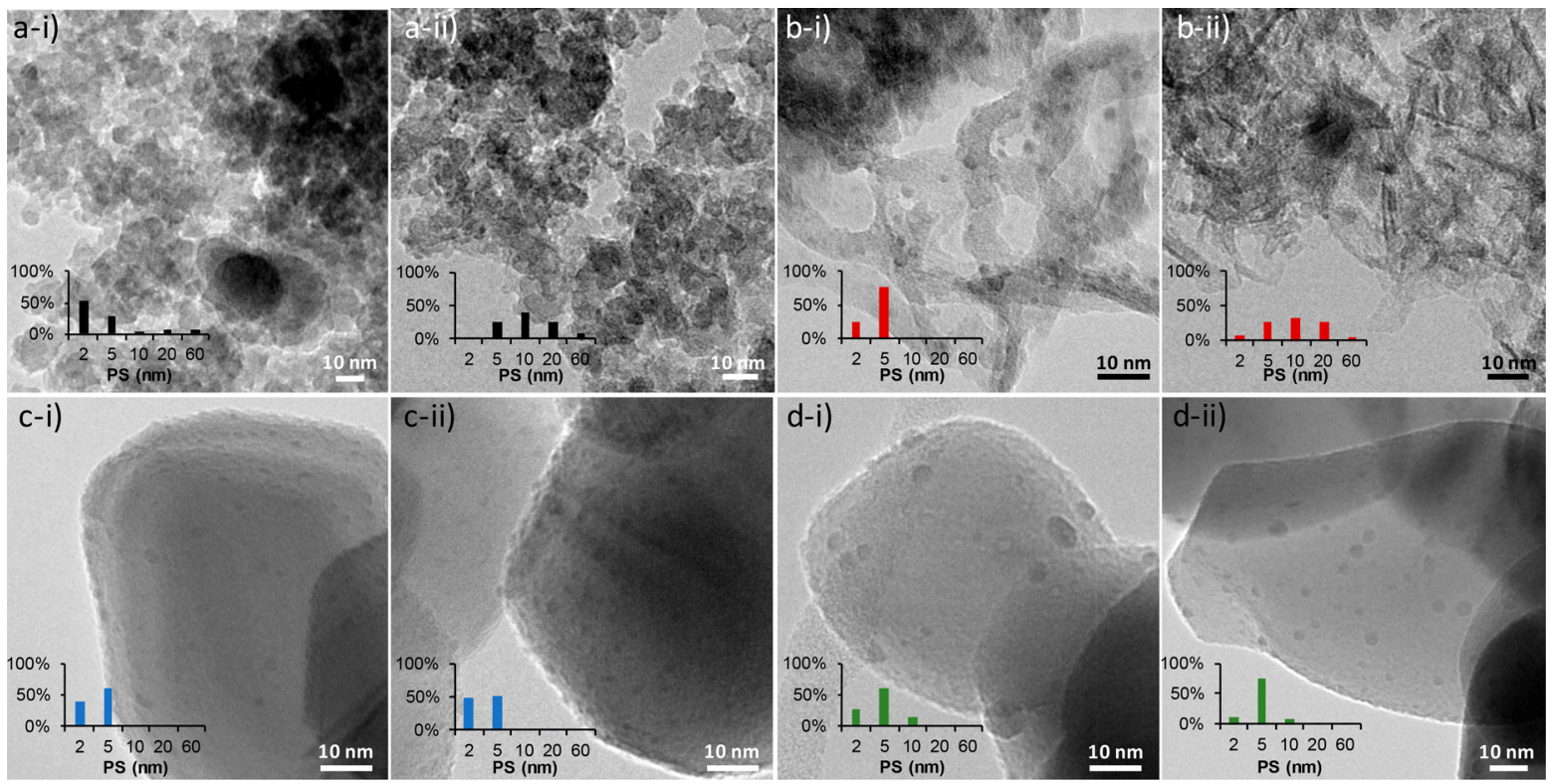

Figure 8. Transmission electron microscopy dark field (TEM-DF) and $\mathrm{Cu}$ particle size distribution of the different catalysts (i) before and (ii) after reaction of (a) $\mathrm{Cu} / \mathrm{SiO}_{2}$, (b) $\mathrm{Cu} / \mathrm{Al}_{2} \mathrm{O}_{3}-\mathrm{SiO}_{2}$, (c) $\mathrm{Cu} / \mathrm{TiO}_{2}$ rutile, and (d) $\mathrm{Cu} / \mathrm{TiO}_{2}$ anatase.
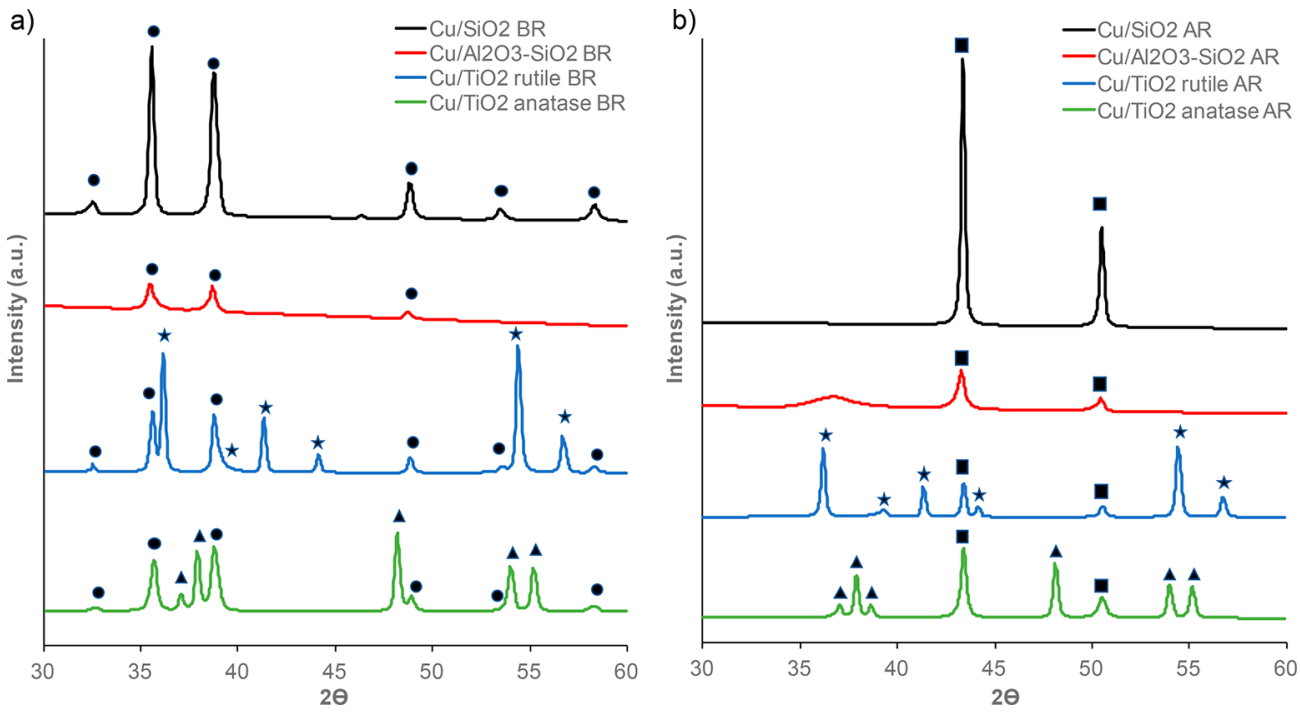

Figure 9. X-ray diffraction of the different catalyst before reaction (a) and after $5 \mathrm{~h}$ of reaction (b), except for $\mathrm{Cu} / \mathrm{SiO}_{2}$ in which the reaction was performed for $20 \mathrm{~h}$. Depending on the composition of the material, three crystalline phases were detected, including $\mathrm{CuO}(\boldsymbol{\bullet}), \mathrm{Cu}(\boldsymbol{\square}), \mathrm{TiO}_{2}$ rutile $(\star)$, and $\mathrm{TiO}_{2}$ anatase $(\boldsymbol{\Lambda})$.

$\left(279 \mathrm{~m}^{2} \mathrm{~g}^{-1}\right)$ were significantly higher than the homologous catalyst supported on $\mathrm{TiO}_{2}$ anatase and rutile $\left(\sim 10 \mathrm{~m}^{2} \mathrm{~g}^{-1}\right)$. After reaction, the surface area of $\mathrm{Cu} / \mathrm{TiO}_{2}$ anatase and rutile slightly increased. This could be due to a reduction of the primary particle size caused by mechanical stress of the catalysts during reaction. ${ }^{69}$ The opposite was observed on $\mathrm{Cu}$ / $\mathrm{Al}_{2} \mathrm{O}_{3}-\mathrm{SiO}_{2}$. In this case, a significant reduction of the surface area was observed ( $\sim 23 \%$ decreased). This could be due to a combination of surface reconstruction, pore collapse, or pore blockage. ${ }^{70}$ In the case of $\mathrm{Cu} / \mathrm{SiO}_{2}$, the decline in surface area was not significant ( $2 \%$ decreased) even after $20 \mathrm{~h}$ of reaction.

To characterize the nanoarchitecture of the $\mathrm{Cu}$ catalysts, HR-TEM was performed on the reduced catalysts before and after reaction (see Figure 8). The microscopic structure of nanosized $\mathrm{SiO}_{2}$ and $\mathrm{Al}_{2} \mathrm{O}_{3}-\mathrm{SiO}_{2}$ catalysts resembled that of agglomerated nanoparticles, which explains the high surface area and mesoporosity of the materials $\left(>200 \mathrm{~m}^{2} \mathrm{~g}^{-1}\right)$. On $\mathrm{TiO}_{2}$ supports, the primary particles showed needle-like structure. In terms of particle size distribution, $\mathrm{SiO}_{2}$ and $\mathrm{Al}_{2} \mathrm{O}_{3}-\mathrm{SiO}_{2}$ had particle sizes ranging from 2 to $60 \mathrm{~nm}$, with an average $\mathrm{Cu}$ particle size of $4 \pm 8 \mathrm{~nm}$ and $3 \pm 1 \mathrm{~nm}$, respectively. As shown in Figure $8 \mathrm{a}-\mathrm{i}$ and $\mathrm{b}-\mathrm{i}$, the particle size distribution was nearly bimodal on $\mathrm{Cu} / \mathrm{SiO}_{2}$ with $75 \%$ of the particles in the range of 2 to $5 \mathrm{~nm}$. The rest of the particles were in the range of 10 to $60 \mathrm{~nm}$. In the case of $\mathrm{Cu} / \mathrm{TiO}_{2}$ rutile and anatase, the average particle size of $\mathrm{Cu}$ nanoparticles was $\sim 3 \pm 2 \mathrm{~nm}$. Notably, these results indicate that the catalytic activity observed on $\mathrm{Cu}$ supported on $\mathrm{SiO}_{2}$ cannot be entirely explained in terms of metal dispersion as the catalysts with the lowest average particle size (i.e., $\mathrm{Cu} / \mathrm{TiO}_{2}$ rutile and anatase) showed lower catalytic activities than those of $\mathrm{Cu} / \mathrm{SiO}_{2}$. 
After the reaction, the $\mathrm{Cu}$ particle size distribution was wider in all of the samples (see Figure 8a-ii to d-ii). The $\mathrm{Cu} / \mathrm{SiO}_{2}$ showed the highest degree of sintering after $20 \mathrm{~h}$ of reaction at $280{ }^{\circ} \mathrm{C}$ with average particle sizes of $9 \pm 3 \mathrm{~nm}$. In the case of $\mathrm{Cu} / \mathrm{Al}_{2} \mathrm{O}_{3}-\mathrm{SiO}_{2}$, the particle size after reaction was wider compared to the fresh catalyst, and the average size was $8 \pm 3$ $\mathrm{nm}$. In contrast, on $\mathrm{Cu} / \mathrm{TiO}_{2}$ rutile and anatase, the average particle only slightly increased. These differences could be associated with the metal-support interactions between $\mathrm{TiO}_{2}$ and $\mathrm{Cu}$ clusters. ${ }^{71}$ For this reason, industrial $\mathrm{Cu}$ catalysts use $\mathrm{ZnO}$ combined with other metal oxides (e.g., Ce, $\mathrm{TiO}_{2}, \mathrm{Al}_{2} \mathrm{O}_{3}$ ) as support. The electronic character of $\mathrm{ZnO}$ favors the interaction with $\mathrm{Cu}$, which in turn enhances stability. ${ }^{9,14,16,28,71-74}$ It is important to remember that care must be taken in the utilization of HRTEM images as the only tool for the assessment of the catalyst particle size distribution. ${ }^{75,76}$ This method is hindered by the small volume of sample analyzed. For this reason, this technique is quite effective when the particle size distribution is narrow, the contrast between the support and metal particles is sufficient (i.e., differences in atomic number are high), the sample-electron beam interaction is not significant, and the sample is homogeneous. Thereby, it is important to combine this technique with complementary characterization (e.g., X-ray diffraction).

XRD characterization of the catalysts was performed to determine the crystalline structure and crystallite size of the $\mathrm{Cu}$ species present on the different catalysts before and after the reforming reaction (see Figure 9a). On $\mathrm{Cu} / \mathrm{SiO}_{2}$, the intense diffraction peaks at $32,35.5,38,48,53$, and $57^{\circ}$ were indexed to the crystalline planes (110), (11 $\overline{1}),(111),(200),(20 \overline{2})$, and (002) of monoclinic tenorite $\mathrm{CuO}_{2}$ (JCPDS 481548). ${ }^{77,78}$ In the case of $\mathrm{Cu} / \mathrm{Al}_{2} \mathrm{O}_{3}-\mathrm{SiO}_{2}$, the peak intensity of the diffraction fingerprint of monoclinic $\mathrm{CuO}$ significantly decreased, which could be associated with either a smaller particle size of $\mathrm{CuO}$ or a lower degree of crystallinity. ${ }^{79}$ The absence of diffraction peaks of $\mathrm{SiO}_{2}$ and $\mathrm{Al}_{2} \mathrm{O}_{3}-\mathrm{SiO}_{2}$ indicated that these high-surface area supports were amorphous. On $\mathrm{CuO}$ supported on $\mathrm{TiO}_{2}$, it was possible to identify both $\mathrm{CuO}$ monoclinic structure and $\mathrm{TiO}_{2}$ rutile and anatase phases. In the case of $\mathrm{Cu} / \mathrm{TiO}_{2}$ rutile, the diffraction peaks 36, 38, 42, 44, 54, and $56^{\circ}$ corresponded to the crystalline planes (101), (200), (111), (210), (211), and (220) of $\mathrm{TiO}_{2}$ rutile phase (JCPDS $820514)$, indicating the high purity of this crystalline material. $\mathrm{On} \mathrm{Cu} / \mathrm{TiO}_{2}$ anatase, the diffractions at $37.5,48,54$, and $55^{\circ}$ were indexed to the crystalline planes (004), (200), (105), and (211) $\mathrm{TiO}_{2}$ rutile phase (JCPDS 21-1272). ${ }^{80}$

After several hours of reaction, the materials were characterized by XRD to determine the crystalline structure of $\mathrm{Cu}$ metal nanoparticles (Figure $9 \mathrm{~b}$ ). In the four catalysts, the absence of $\mathrm{CuO}$ monoclinic reflections indicates that reduction of $\mathrm{Cu}^{2+}$ to $\mathrm{Cu}^{0}$ was completed under these conditions. While it is possible that $\mathrm{CuO}$ is still present in the system, the fraction of metal oxide ranged between 2 and $10 \%$ according to TPR data (Table S5). On $\mathrm{Cu} / \mathrm{SiO}_{2}$ and $\mathrm{Cu} / \mathrm{Al}_{2} \mathrm{O}_{3}-\mathrm{SiO}_{2}$, diffractions at 44 and $50^{\circ}$ were attributed to the (111) and (200) planes that are characteristic of the faced centered cubic (fcc) structure of metallic $\mathrm{Cu}$ with the space group of $\mathrm{Fm} 3 \mathrm{~m}$ (JCPDS 85-1326). ${ }^{81}$ The intensity and broadening of the reflections, however, indicated that on $\mathrm{SiO}_{2}$ the particles were more crystalline and larger compared to $\mathrm{Al}_{2} \mathrm{O}_{3}-\mathrm{SiO}_{2}$. On the $\mathrm{TiO}_{2}$ supported catalysts, it was possible to identify the rutile and anatase crystalline phases together with metallic $\mathrm{Cu}$ with an fcc structure. The analysis of the size of $\mathrm{CuO}$ and $\mathrm{Cu}$ crystalline domains using the Debye-Scherrer model (eq 4) showed important differences between the different catalysts (see Table S7). Initially, the oxidized catalysts had average crystallite sizes of $\mathrm{CuO}$ ranging from 27 to $40 \mathrm{~nm}$. Upon reduction at $300{ }^{\circ} \mathrm{C}$ in $\mathrm{H}_{2}$, the crystallite size increased significantly in all the catalysts, except on $\mathrm{SiO}_{2}-\mathrm{Al}_{2} \mathrm{O}_{3}$. Under reduced environments at high temperature, catalyst sintering is accelerated, which leads to particle growth. The process is strongly related to the initial dispersion of the metals, ${ }^{82-84}$ the $\mathrm{Cu}$ precursor, ${ }^{85}$ the presence of additives, ${ }^{86}$ metal-support interaction, ${ }^{54}$ reduction temperature, ${ }^{87}$ and spatial distribution of the metal clusters. ${ }^{71}$ Therefore, it is possible that the drastic particle growth observed during reduction observed on $\mathrm{Cu}$ / $\mathrm{SiO}_{2}$ was caused by the relatively weak interaction of $\mathrm{Cu}-\mathrm{SiO}_{2}$ support. In contrast, the stronger metal support interactions of $\mathrm{Cu}$ with $\mathrm{TiO}_{2}$ and $\mathrm{Al}_{2} \mathrm{O}_{3}-\mathrm{SiO}_{2}$ led to a lower sintering rate. ${ }^{74,88}$ The average crystallite size showed significant deviation when compared to the HRTEM data. While it is true that crystallite size and particle sizes are not necessarily equal, the discrepancies herein observed could be due to the limitations of the HRTEM to capture large $\mathrm{Cu}$ clusters. In turn, the particle size distribution was artificially shifted to smaller sizes.

The results herein presented indicate that the activity, selectivity, and stability of the different catalysts during the methanol reforming reaction are strongly influenced by the acidity of the support, textural properties of the support, metal-support affinity, and to lesser extent the metal dispersion. In the case of $\mathrm{Cu} / \mathrm{SiO}_{2}$, the high surface area and moderate acidity seemed to result in high catalytic activity in terms of mass of the catalyst and high selectivity to $\mathrm{H}_{2}$ even after long periods of time on stream $(5-80 \mathrm{~h})$.

\section{CONCLUSIONS}

A detailed study of methanol steam reforming reaction $\mathrm{Cu}$ catalyst supported on different metal oxides was performed to establish structure-activity relationships. This was accomplished by combining steam reforming experiments under different reaction conditions using $\mathrm{Cu}$ catalyst supported on nanosized $\mathrm{SiO}_{2}, \mathrm{Al}_{2} \mathrm{O}_{3}-\mathrm{SiO}_{2}, \mathrm{TiO}_{2}$ rutile, and $\mathrm{TiO}_{2}$ anatase. The results indicate that on highly acidic supports (e.g., $\mathrm{Al}_{2} \mathrm{O}_{3}-\mathrm{SiO}_{2}$ ) the conversion of methanol rapidly decreased with the TOS. Thermal gravimetric analysis of the spent catalyst indicated the presence of carbon deposits, which could be responsible for the fast rates of deactivation. On $\mathrm{TiO}_{2}$ anatase, the catalytic activity and stability were significantly lower than that obtained on homologous $\mathrm{TiO}_{2}$ rutile. This observation was tentatively attributed to the differences in adsorbate-surface binding on $\mathrm{TiO}_{2}$ rutile and anatase. $\mathrm{Cu}$ supported on nanosized $\mathrm{SiO}_{2}$ showed the highest catalytic activity and selectivity among the materials screened. Steady state operation of $\mathrm{Cu} / \mathrm{SiO}_{2}$ catalyst was performed for over 80 $\mathrm{h}$ of reaction at low and high pressures and temperatures with no changes in activity and selectivity. However, metal sintering was observed after reaction by means of HRTEM and XRD. This deactivation was most likely masked by the high level of methanol conversion $(\sim 80 \%)$. The high activity and selectivity of $\mathrm{Cu} / \mathrm{SiO}_{2}$ were attributed to the low acid site concentration. Notably, $\mathrm{Cu}$ supported on $\mathrm{TiO}_{2}$ rutile showed very high activity and stability $\left(771 \mu \mathrm{mol} \mathrm{H}_{2} \cdot \mathrm{min}^{-1} \cdot \mathrm{g}_{\text {cat }}{ }^{-1}\right)$, which is rather unexpected for a catalyst with rather low specific surface area $\left(10 \mathrm{~m}^{2} \mathrm{~g}^{-1}\right)$. 


\section{ASSOCIATED CONTENT}

\section{S Supporting Information}

The Supporting Information is available free of charge on the ACS Publications website at DOI: 10.1021/acs.iecr.8b02488.

Additional details on the following results of catalyst characterization for the different catalysts herein employed, including peak distribution for the temperature-programmed reduction, deconvolution of the temperature-programmed desorption of $\mathrm{NH}_{3}, \mathrm{~N}_{2}$ desorption isotherms, $\mathrm{H}_{2}$ consumption, extent of $\mathrm{CuO}$ reduction, carbon deposits from thermal gravimetric analysis, and crystallite size; some supplementary results related to the catalytic activity, including product distribution as a function of time on stream (TOS) for $\mathrm{Cu} / \mathrm{SiO}_{2}$, hydrogen productivity as a function of the catalyst to feed ratio for the $\mathrm{Cu} / \mathrm{SiO}_{2}$ catalyst, WeiszPrater criterion obtained for the different catalysts utilized for the reaction experiments, conversion, activity and selectivity for the different catalysts, conversion and product distribution as a function of temperature on $\mathrm{Cu} / \mathrm{SiO}_{2}$ (PDF)

\section{AUTHOR INFORMATION}

\section{Corresponding Author}

*Telephone: +31 5348971 15. E-mail: j.a.fariaalbanese@ utwente.nl.

\section{ORCID $\odot$}

Juan Carlos Serrano-Ruiz: https://orcid.org/0000-0002-9078-7390 Jimmy Faria: 0000-0002-8920-3538

Notes

The authors declare no competing financial interest.

\section{ACKNOWLEDGMENTS}

The authors acknowledge Abengoa Research for the financial support of this project and the University of Seville for the characterization of the materials by HR-TEM and XRD. J.C.S.R. would like to acknowledge the Spanish Ministry of Science, Innovation and Universities for financial support under the Ramón y Cajal Program (grant RYC-2015-19230).

\section{REFERENCES}

(1) Haryanto, A.; Fernando, S.; Murali, N.; Adhikari, S. Current Status of Hydrogen Production Techniques by Steam Reforming of Ethanol: A Review. Energy Fuels 2005, 19 (19), 2098-2106.

(2) Ratnasamy, C.; Wagner, J. P. Water Gas Shift Catalysis. Catal. Rev.: Sci. Eng. 2009, 51 (3), 325-440.

(3) Palo, D. R.; Dagle, R. A.; Holladay, J. D. Methanol Steam Reforming for Hydrogen Production. Chem. Rev. 2007, 107 (107), $3992-4021$.

(4) Sá, S.; Silva, H.; Brandão, L.; Sousa, J. M.; Mendes, A. Catalysts for methanol steam reforming - A review. Appl. Catal., B 2010, 99, 43-57.

(5) Yong-feng, L.; Xin-fa, D.; Wei-ming, L. Effects of ZrO2promoter on catalytic performance of $\mathrm{CuZnAlO}$ catalysts for production of hydrogen by steam reforming of methanol. Int. J. Hydrogen Energy 2004, 29, 1617-1621.

(6) Liu, Y.; Hayakawa, T.; Suzuki, K.; Hamakawa, S.; et al. Highly active copper/ceria catalysts for steam reforming of methanol. Appl. Catal., A 2002, 223, 137-145.

(7) Peppley, B. A.; Amphlett, J. C.; Kearns, L. M.; Mann, R. F. Methanol-Steam Reforming on $\mathrm{Cu} / \mathrm{ZnO} / \mathrm{Al} 2 \mathrm{O} 3$. Part 1: the reaction network. Appl. Catal., A 1999, 179, 21-29.
(8) Peppley, B. A.; Amphlett, J. C.; Kearns, L. M.; Mann, R. F. Methanol-Steam Reforming on $\mathrm{Cu} / \mathrm{ZnO} / \mathrm{Al} 2 \mathrm{O} 3$. Part 2. A comprehensive kinetic model. Appl. Catal., A 1999, 179, 31-49.

(9) Lee, J. K.; Ko, J. B.; Kim, D. H. Methanol steam reforming over $\mathrm{Cu} / \mathrm{ZnO} / \mathrm{Al} 2 \mathrm{O} 3$ catalyst: kinetics and effectiveness factor. Appl. Catal., A 2004, 278, 25-35.

(10) Agrell, J.; Birgersson, H.; Boutonnet, M. Steam reforming of methanol over a $\mathrm{Cu} / \mathrm{ZnO} / \mathrm{Al} 2 \mathrm{O} 3$ catalyst: a kinetic analysis and strategies for suppression of CO formation. J. Power Sources 2002, $106,249-257$.

(11) Matsumura, Y.; Ishibe, H. High temperature steam reforming of methanol over $\mathrm{Cu} / \mathrm{ZnO} / \mathrm{ZrO} 2$ catalysts. Appl. Catal., B 2009, 91, 524-532.

(12) Jiang, C. J.; Trimm, D. L.; Wainwright, M. S.; Cant, N. W. Kinetic study of steam reforming of methanol over copper-based catalysts. Appl. Catal., A 1993, 93, 245-255.

(13) Takezawa, N.; Iwasa, N. Steam reforming and dehydrogenation of methanol: Difference in the catalytic functions of copper and group VIII metals. Catal. Today 1997, 36, 45-56.

(14) Kniep, B. L.; Ressler, T.; Rabis, A.; Girgsdies, F.; Baenitz, M.; Steglich, F.; Schlogl, R. Rational Design of Nanostructured CopperZinc Oxide Catalysts for the Steam Reforming of Methanol. Angew. Chem., Int. Ed. 2004, 43, 112-115.

(15) Agrell, J.; Birgersson, H.; Boutonnet, M.; Melián-cabrera, I.; Navarro, R. M.; Fierro, J. L. G.; et al. Production of hydrogen from methanol over $\mathrm{Cu} / \mathrm{ZnO}$ catalysts promoted by $\mathrm{ZrO} 2$ and $\mathrm{Al} 2 \mathrm{O} 3$. J. Catal. 2003, 219, 389-403.

(16) Shishido, T.; Yamamoto, Y.; Morioka, H.; Takaki, K.; Takehira, $\mathrm{K}$. Active $\mathrm{Cu} / \mathrm{ZnO}$ and $\mathrm{Cu} / \mathrm{ZnO} / \mathrm{Al} 2 \mathrm{O} 3$ catalysts prepared by homogeneous precipitation method in steam reforming of methanol. Appl. Catal., A 2004, 263, 249-253.

(17) Jakdetchai, O.; Takayama, N.; Nakajima, T. Activity Enhancement of CuZn-impregnated FSM-16 by Modification with 1,3Butanediol for Steam Reforming of Methanol. Kinet. Catal. 2005, 46 (1), 56-64.

(18) Jones, S. D.; Hagelin-weaver, H. E. Steam reforming of methanol over $\mathrm{CeO} 2$ - and $\mathrm{ZrO} 2$-promoted $\mathrm{Cu}-\mathrm{ZnO}$ catalysts supported on nanoparticle Al2O3. Appl. Catal., B 2009, 90, 195-204.

(19) Patel, S.; Pant, K. K. Selective production of hydrogen via oxidative steam reforming of methanol using $\mathrm{Cu}-\mathrm{Zn}-\mathrm{Ce}-\mathrm{Al}$ oxide catalysts. Chem. Eng. Sci. 2007, 62, 5436-5443.

(20) Yang, S.; He, J.; Zhang, N.; Sui, X.; Zhang, L.; Yang, Z. Effect of rare-earth element modification on the performance of $\mathrm{Cu} / \mathrm{ZnAl}$ catalysts derived from hydrotalcite precursor in methanol steam reforming. J. Fuel Chem. Technol. 2018, 46 (2), 179-188.

(21) Tajrishi, O. Z.; Taghizadeh, M.; Kiadehi, A. D. Methanol steam reforming in a microchannel reactor by $\mathrm{Zn}$-, Ce- and $\mathrm{Zr}$ - modified mesoporous Cu/SBA-15 nanocatalyst. Int. J. Hydrogen Energy 2018, 43, 14103-14120.

(22) Sanches, S. G.; Flores, J. H.; da Silva, M. I. P. Cu/ZnO and Cu/ $\mathrm{ZnO} / \mathrm{ZrO} 2$ catalysts used for methanol steam reforming. Mol. Catal. 2018, 454, 55-62.

(23) Ajamein, H.; Haghighi, M.; Alaei, S. The role of various fuels on microwave-enhanced combustion synthesis of $\mathrm{CuO} / \mathrm{ZnO} / \mathrm{Al} 2 \mathrm{O} 3$ nanocatalyst used in hydrogen production via methanol steam reforming. Energy Convers. Manage. 2017, 137, 61-73.

(24) Bagherzadeh, S. B.; Haghighi, M. Plasma-enhanced comparative hydrothermal and coprecipitation preparation of $\mathrm{CuO} / \mathrm{ZnO} / \mathrm{Al} 2 \mathrm{O} 3$ nanocatalyst used in hydrogen production via methanol steam reforming. Energy Convers. Manage. 2017, 142, 452-465.

(25) Liu, X.; Toyir, J.; Ramirez de la Piscina, P.; Homs, N. Hydrogen production from methanol steam reforming over $\mathrm{Al} 2 \mathrm{O} 3-$ and $\mathrm{ZrO} 2-$ modified. Int. J. Hydrogen Energy 2017, 42, 13704-13711.

(26) Takezawa, N.; Kobayashi, H.; Hirose, A.; Shimokawabe, M.; Takahashi, K. Steam reforming of methanol on copper-silica catalysts; effect of copper loading and calcination temperature on the reaction. Appl. Catal. 1982, 4, 127-134.

(27) Shishido, T.; Yamamoto, Y.; Morioka, H.; Takehira, K. Production of hydrogen from methanol over $\mathrm{Cu} / \mathrm{ZnO}$ and $\mathrm{Cu} /$ 
$\mathrm{ZnO} / \mathrm{Al} 2 \mathrm{O} 3$ catalysts prepared by homogeneous precipitation: Steam reforming and oxidative steam reforming. J. Mol. Catal. A: Chem. 2007, 268, 185-194.

(28) Matter, P. H.; Braden, D. J.; Ozkan, U. S. Steam reforming of methanol to $\mathrm{H} 2$ over nonreduced $\mathrm{Zr}$-containing $\mathrm{CuO} / \mathrm{ZnO}$ catalysts. J. Catal. 2004, 223, 340-351.

(29) Yi, N.; Si, R.; Saltsburg, H.; Flytzani-stephanopoulos, M. Steam reforming of methanol over ceria and gold-ceria nanoshapes. Appl. Catal., B 2010, 95, 87-92.

(30) Su, T.-B.; Rei, M.-H. Steam Reforming of Methanol over Nickel and Copper Catalysts. J. Chin. Chem. Soc. 1991, 38 (6), 535-541.

(31) Huang, Y.; Wang, S.; Tsai, A.; Kameoka, S. Reduction behaviors and catalytic properties for methanol steam reforming of Cu-based spinel compounds $\mathrm{CuX} 2 \mathrm{O} 4(\mathrm{X}=\mathrm{Fe}, \mathrm{Mn}, \mathrm{Al}, \mathrm{La})$. Ceram. Int. 2014, 40, 4541-4551.

(32) Lebarbier, V.; Dagle, R.; Conant, T.; Vohs, J. M.; Datye, A. K.; Wang, Y. CO/FTIR Spectroscopic Characterization of $\mathrm{Pd} / \mathrm{ZnO} /$ Al2O3 Catalysts for Methanol Steam Reforming. Catal. Lett. 2008, $122,223-227$.

(33) Oguchi, H.; Nishiguchi, T.; Matsumoto, T.; Kanai, H.; Utani, K.; Matsumura, Y.; Imamura, S. Steam reforming of methanol over $\mathrm{Cu} / \mathrm{CeO} 2 / \mathrm{ZrO} 2$ catalysts. Appl. Catal., A 2005, 281, 69-73.

(34) Tsai, M.; Wang, J.; Shen, C.; Yeh, C. Promotion of a copperzinc catalyst with rare earth for the steam reforming of methanol at low temperatures. J. Catal. 2011, 279, 241-245.

(35) Kim, S.; Kang, M. Hydrogen production from methanol steam reforming over $\mathrm{Cu}-\mathrm{Ti}-\mathrm{P}$ oxide catalysts. J. Ind. Eng. Chem. 2012, 18 (3), 969-978.

(36) Pongstabodee, S.; Monyanon, S.; Luengnaruemitchai, A. Hydrogen production via methanol steam reforming over $\mathrm{Au} / \mathrm{CuO}$, $\mathrm{Au} / \mathrm{CeO} 2$, and $\mathrm{Au} / \mathrm{CuO}-\mathrm{CeO} 2$ catalysts prepared by depositionprecipitation. J. Ind. Eng. Chem. 2012, 18 (4), 1272-1279.

(37) Tahay, P.; Khani, Y.; Jabari, M.; Bahadoran, F.; Safari, N. General Highly porous monolith/TiO2 supported $\mathrm{Cu}, \mathrm{Cu}-\mathrm{Ni}, \mathrm{Ru}$, and Pt catalysts in methanol steam reforming process for $\mathrm{H} 2$ generation. Appl. Catal., A 2018, 554, 44-53.

(38) Taghizadeh, M.; Akhoundzadeh, H.; Rezayan, A.; Sadeghian, M. Excellent catalytic performance of 3D-mesoporous KIT-6 supported $\mathrm{Cu}$ and $\mathrm{Ce}$ nanoparticles in methanol steam reforming. Int. J. Hydrogen Energy 2018, 43, 10926-10937.

(39) Phongboonchoo, Y.; Thouchprasitchai, N.; Pongstabodee, S. Hydrogen production with a low carbon monoxide content via methanol steam reforming over CuxCeyMgz/Al2O3 catalysts: Optimization and stability. Int. J. Hydrogen Energy 2017, 42, 12220-12235.

(40) Jampa, S.; Jamieson, A. M.; Chaisuwan, T.; Luengnaruemitchai, A.; Wongkasemjit, S. Achievement of hydrogen production from autothermal steam reforming of methanol over $\mathrm{Cu}$-loaded mesoporous $\mathrm{CeO} 2$ and $\mathrm{Cu}$-loaded mesoporous $\mathrm{CeO} 2 \mathrm{ZrO} 2$ catalysts. Int. J. Hydrogen Energy 2017, 42, 15073-15084.

(41) Lunkenbein, T.; Girgsdies, F.; Kandemir, T.; Thomas, N.; Behrens, M.; Schlögl, R.; Frei, E. Bridging the Time Gap: A Copper/ Zinc Oxide/Aluminum Oxide Catalyst for Methanol Synthesis Studied under Industrially Relevant Conditions and Time Scales. Angew. Chem., Int. Ed. 2016, 55 (41), 12708-12712.

(42) Behrens, M.; Studt, F.; Kasatkin, I.; Kühl, S.; Hävecker, M.; Abild-pedersen, F.; Zander, S.; Girgsdies, F.; Kurr, P.; Kniep, B.; et al. The Active Site of Methanol Synthesis over $\mathrm{Cu} / \mathrm{ZnO} / \mathrm{Al} 2 \mathrm{O} 3$ Industrial Catalysts. Science (Washington, DC, U. S.) 2012, 336, 893-898.

(43) Manzolini, G.; Jansen, D. Economic analysis of systems for electrical energy and hydrogen production: fundamentals and application to two membrane reactor processes. In Handbook of Membrane Reactors: Vol. 2: Reactor Types and Industrial Applications; Basile, A., Ed.; Woodhead Publishing Limited: Cambridge, 2013; pp 528-550.

(44) Santarelli, M.; Medina, P.; Call, M. Fitting regression model and experimental validation for a high-pressure PEM electrolyzer. Int. J. Hydrogen Energy 2009, 34, 2519-2530.
(45) Marangio, F.; Santarelli, M.; Cal1, M. Theoretical model and experimental analysis of a high pressure PEM water electrolyser for hydrogen production. Int. J. Hydrogen Energy 2009, 34, 1143-1158.

(46) Watson, B. A.; Barteau, M. A. Atomic Force Microscopy Imaging of Ti02 Surfaces Active for C-C Bond Formation Reactions in Ultrahigh Vacuum. Chem. Mater. 1994, 6 (16), 771-779.

(47) Barteau, M. A. Organic Reactions at Well-Defined Oxide Surfaces. Chem. Rev. 1996, 96, 1413-1430.

(48) Rekoske, J. E.; Barteau, M. A. Isothermal Reduction Kinetics of Titanium Dioxide-Based Materials. J. Phys. Chem. B 1997, 101 (7), $1113-1124$.

(49) Bukhavtsova, N. M.; Ostrovskii, N. M. Catalytic reaction accompanied by capillary condensation. 3. Infuence on reaction kinetics and dynamics. React. Kinet. Catal. Lett. 1998, 65 (2), 321329.

(50) Singh, U. K.; Vannice, M. A. Kinetics of liquid-phase hydrogenation reactions over supported metal catalysts - a review. Appl. Catal., A 2001, 213, 1-24.

(51) Mukherjee, S.; Vannice, M. A. Solvent effects in liquid-phase reactions II. Kinetic modeling for citral hydrogenation. J. Catal. 2006, 243 (1), 131-148.

(52) Madon, R. J.; O’Connell, J. P.; Boudart, M. Catalytic hydrogenation of cyclohexene: Part II. Liquid phase reaction on supported platinum in a gradientless slurry reactor. AIChE J. 1978, 24 (5), 904-911.

(53) Madon, R. J.; Iglesia, E. Catalytic reaction rates in thermodynamically non-ideal systems. J. Mol. Catal. A: Chem. 2000, $163(1-2), 189-204$.

(54) Haller, G. L.; Resasco, D. E. Metal-Support Interaction: Group Vlll Metals and Reducible Oxides. Adv. Catal. 1989, 36, 173-235.

(55) Che, M.; Bennett, C. The Influence of Particle Size on the Catalytic Properties of Supported Metals. Adv. Catal. 1989, 36, 55172.

(56) Hicks, R. F.; Fleisch, T. H.; Bell, A. T. An XPS Study of MetalSupport Interactions on $\mathrm{Pd} / \mathrm{SiO} 2$ and $\mathrm{Pd} / \mathrm{La} 2 \mathrm{O} 3$. J. Catal. 1984, 87, 398-413.

(57) Sagar, G. V.; Rao, R.; Srikanth, C. S.; Chary, K. V. R. Dispersion and Reactivity of Copper Catalysts Supported on Al2O3-ZrO2. J. Phys. Chem. B 2006, 110, 13881-13888.

(58) Zhao, E. W.; Zheng, H.; Ludden, K.; Xin, Y.; Hagelin-Weaver, H. E.; Bowers, C. R. Strong Metal-Support Interactions Enhance the Pairwise Selectivity of Parahydrogen Addition over Ir/TiO2. ACS Catal. 2016, 6, 974-978.

(59) Demmin, R. A.; Gorte, R. J. Design Parameters for Temperature-Programmed from a Packed Bed. J. Catal. 1984, 90, $32-39$.

(60) Gorte, R. J. Temperature-programmed desorption for the characterization oxide catalysts. Catal. Today 1996, 28, 405-414.

(61) Kouva, S.; Kanervo, J.; Schüßler, F.; Olindo, R.; Lercher, J. A.; Krause, O. Sorption and diffusion parameters from vacuum-TPD of ammonia on H-ZSM-5. Chem. Eng. Sci. 2013, 89, 40-48.

(62) Coppens, M. O. Characterization of fractal surface roughness and its influence on diffusion and reaction. Colloids Surf., A 2001, 187-188, 257-265.

(63) Aranda-Pérez, N.; Ruiz, M. P.; Echave, J.; Faria, J. Enhanced Activity and Stability of Ru-TiO2 Rutile for Liquid Phase Ketonization. Appl. Catal., A 2017, 531, 106-118.

(64) Pham, T. N.; Shi, D.; Sooknoi, T.; Resasco, D. E. Aqueousphase ketonization of acetic acid over $\mathrm{Ru} / \mathrm{TiO} 2 /$ carbon catalysts. $J$. Catal. 2012, 295, 169-178.

(65) Mapes, J. E.; Eischens, R. P. TThe infrared spectra of ammonia chemisorbed on cracking catalysts. J. Phys. Chem. 1954, 58, 10591062.

(66) Milliken, T. H. J.; Mills, G. A.; Oblad, A. G. The chemical characteristics and structure of cracking catalysts. Discuss. Faraday Soc. 1950, 8, 279-290.

(67) Huang, X.; Cant, N. W.; Wainwright, M. S.; Ma, L. The dehydrogenation of methanol to methyl formate Part I: Kinetic 
studies using copper-based catalysts. Chem. Eng. Process. 2005, 44, 393-402.

(68) Yarulina, I.; Chowdhury, A. D.; Meirer, F.; Weckhuysen, B. M.; Gascon, J. Recent trends and fundamental insights in the methanol-tohydrocarbons process. Nat. Catal. 2018, 1 (6), 398-411.

(69) Wu, D.; Song, L.; Zhang, B.; Li, Y. Effect of the mechanical failure of catalyst pellets on the pressure drop of a reactor. Chem. Eng. Sci. 2003, 58, 3995-4004.

(70) Zhang, L.; Chen, K.; Chen, B.; White, J. L.; Resasco, D. E. Factors that Determine Zeolite Stability in Hot Liquid Water. J. Am. Chem. Soc. 2015, 137 (36), 11810-11819.

(71) Prieto, G.; Zečević, J.; Friedrich, H.; de Jong, K. P.; de Jongh, P. E. Towards stable catalysts by controlling collective properties of supported metal nanoparticles. Nat. Mater. 2013, 12 (1), 34-39.

(72) Asprey, S. P.; Wojciechowski, B. W.; Peppley, B. A. Kinetic studies using temperature-scanning: the steam-reforming of methanol. Appl. Catal., A 1999, 179, 51-70.

(73) Robbins, J. L.; Kelkar, C. P.; Iglesia, E.; DeRites, B. Methanol synthesis over $\mathrm{C} \mathrm{u} / \mathrm{SiO} 2$ catalysts. Catal. Lett. 1991, 10, 1-10.

(74) Liu, Y.; Hayakawa, T.; Tsunoda, T.; Suzuki, K.; Hamakawa, S.; Murata, K.; Shiozaki, R.; Ishii, T.; Kumagai, M. Steam reforming of methanol over $\mathrm{Cu} / \mathrm{CeO} 2$ catalysts studied in comparison with $\mathrm{Cu}$ / $\mathrm{ZnO}$ and $\mathrm{Cu} / \mathrm{Zn}(\mathrm{Al}) \mathrm{O}$ catalysts. Top. Catal. 2003, 22 (3-4), 205213.

(75) Adams, C. R.; Benesi, H. A.; Meisenheimer, R. G. Particle Size Determination of Supported Catalytic Materials: Platinum on Silica Gel. J. Catal. 1962, 1, 336-344.

(76) Harris, P. Growth and Structure of Supported Metal Catalyst Particles. Int. Mater. Rev. 1995, 40 (3), 97-115.

(77) Meghana, S.; Kabra, P.; Chakraborty, S.; Padmavathy, N. Understanding the pathway of antibacterial activity of copper oxide nanoparticles. RSC Adv. 2015, 5, 12293-12299.

(78) Kayani, Z. N.; Umer, M.; Riaz, S.; Naseem, S. Characterization of Copper Oxide Nanoparticles Fabricated by the Sol-Gel Method. J. Electron. Mater. 2015, 44 (10), 3704-3709.

(79) Jensen, H.; Pedersen, J. H.; Jørgensen, J. E.; Pedersen, J. S.; Joensen, K. D.; Iversen, S. B.; Søgaard, E. G. Determination of size distributions in nanosized powders by TEM, XRD, and SAXS. J. Exp. Nanosci. 2006, 1 (3), 355-373.

(80) Yan, J.; Wu, G.; Guan, N.; Li, L.; Li, Z.; Cao, X. Understanding the effect of surface/bulk defects on the photocatalytic activity of TiO2: anatase versus rutile. Phys. Chem. Chem. Phys. 2013, 15, 10978-10988.

(81) Dung Dang, T. M.; Tuyet Le, T. T.; Fribourg-Blanc, E.; Chien Dang, M. The influence of solvents and surfactants on the preparation of copper nanoparticles by a chemical reduction method. Adv. Nat. Sci.: Nanosci. Nanotechnol. 2011, 2 (2), 025004.

(82) Kim, W.; Mohaideen, K. K.; Seo, D. J.; Yoon, W. L. Methanolsteam reforming reaction over $\mathrm{Cu}-\mathrm{Al}$-based catalysts derived from layered double hydroxides. Int. J. Hydrogen Energy 2017, 42, 20812087.

(83) Azenha, C. S. R.; Mateos-pedrero, C.; Queirós, S.; Concepción, P.; Mendes, A. Environmental Innovative $\mathrm{ZrO} 2$-supported CuPd catalysts for the selective production of hydrogen from methanol steam reforming. Appl. Catal., B 2017, 203, 400-407.

(84) Gates, B. C. Supported Metal Clusters: Synthesis, Structure, and Catalysis. Chem. Rev. 1995, 95, 511-522.

(85) Qin, F.; Liu, Y.; Qing, S.; Hou, X.; Gao, Z. Cu-Al spinel as a sustained release catalyst for $\mathrm{H} 2$ production from methanol steam reforming: Effects of different copper sources. J. Fuel Chem. Technol. 2017, 45 (12), 1481-1488.

(86) Lei, Y.; Luo, Y.; Li, X.; Lu, J.; Mei, Z.; Peng, W.; Chen, R.; Chen, K.; Chen, D.; He, D. The role of samarium on $\mathrm{Cu} / \mathrm{Al} 2 \mathrm{O} 3$ catalyst in the methanol steam reforming for hydrogen production. Catal. Today 2018, 307, 162-168.

(87) Coq, B.; Dutartre, R.; Figueras, F.; Tazi, T. Particle Size, Precursor, and Support Effects in the Hydrogenolysis of Alkanes Over Supported Rhodium Catalysts. J. Catal. 1990, 122, 438-447.
(88) Mrad, M.; Gennequin, C.; Aboukaïs, A.; Abi-aad, E. Cu/Znbased catalysts for $\mathrm{H} 2$ production via steam reforming of methanol. Catal. Today 2011, 176, 88-92. 